ARTICLE

DOI: $10.1038 / s 41467-018-04463-7$

\title{
A coastal coccolithophore maintains pH homeostasis and switches carbon sources in response to ocean acidification
}

\author{
Yi-Wei Liu (10 1,2,3, Robert A. Eagle 2,4,5, Sarah M. Aciego 1,6, Rosaleen E. Gilmore ${ }^{5}$ \& Justin B. Ries (1) ${ }^{7}$
}

Ocean acidification will potentially inhibit calcification by marine organisms; however, the response of the most prolific ocean calcifiers, coccolithophores, to this perturbation remains under characterized. Here we report novel chemical constraints on the response of the widespread coccolithophore species Ochrosphaera neapolitana (O. neapolitana) to changing$\mathrm{CO}_{2}$ conditions. We cultured this algae under three $\mathrm{pCO}_{2}$-controlled seawater $\mathrm{pH}$ conditions (8.05, 8.22, and 8.33). Boron isotopes within the algae's extracellular calcite plates show that this species maintains a constant $\mathrm{pH}$ at the calcification site, regardless of $\mathrm{CO}_{2}$-induced changes in $\mathrm{pH}$ of the surrounding seawater. Carbon and oxygen isotopes in the algae's calcite plates and carbon isotopes in the algae's organic matter suggest that $O$. neapolitana utilize carbon from a single internal dissolved inorganic carbon (DIC) pool for both calcification and photosynthesis, and that a greater proportion of dissolved $\mathrm{CO}_{2}$ relative to $\mathrm{HCO}_{3}{ }^{-}$enters the internal DIC pool under acidified conditions. These two observations may explain how O. neapolitana continues calcifying and photosynthesizing at a constant rate under different atmospheric- $p \mathrm{CO}_{2}$ conditions.

\footnotetext{
${ }^{1}$ Department of Earth and Environmental Sciences, University of Michigan, 2534 C. C. Little Building, 1100 North University Avenue, Ann Arbor, MI 48109 USA. ${ }^{2}$ Université de Brest, UBO, CNRS, IRD, Ifremer, Institut Universitaire Européen de la Mer, LEMAR, Rue Dumont d’Urville, 29280 Plouzané, France. ${ }^{3}$ Institute of Earth Sciences, Academia Sinica, 128, Sec. 2, Academia Road, Nangang 11529 Taipei, Taiwan. ${ }^{4}$ Institute of the Environment and Sustainability, University of California - Los Angeles, La Kretz Hall, 619 Charles E. Young Dr. E \#300, Los Angeles, CA 90024, USA. ${ }^{5}$ Department of Atmospheric and Oceanic Sciences, University of California - Los Angeles, Math Sciences Building, 520 Portola Plaza, Los Angeles, CA 90095, USA. ${ }^{6}$ Department of Geology and Geophysics, University of Wyoming, 1000 E. University Avenue, Laramie, WY 82071-2000, USA. 7 Department of Marine and Environmental Sciences, Marine Science Center, Northeastern University, 430 Nahant Road, Nahant, MA 01908, USA. Correspondence and requests for materials should be addressed to Y.-W.L. (email: liuyiwei@earth.sinica.edu.tw) or to R.A.E. (email: robeagle@g.ucla.edu)
} 
C $\mathrm{O}_{2}$-induced ocean acidification (OA) is reducing the calcium carbonate saturation state of seawater, potentially making it harder for calcifying marine organisms to build their shells and skeletons ${ }^{1-3}$. However, controlled laboratory experiments suggest that organisms have extremely varied calcification responses to $\mathrm{CO}_{2}$-induced $\mathrm{OA}$, with some species exhibiting resilience or even showing positive calcification responses to high- $\mathrm{CO}_{2}$ conditions ${ }^{4-11}$. It has been hypothesized that such diverse responses to $\mathrm{CO}_{2}$-induced $\mathrm{OA}$ may result from differing capacities of marine calcifying organisms to actively remove protons, $\mathrm{H}^{+}$, from their calcifying medium, thereby raising the carbonate ion concentration, $\left[\mathrm{CO}_{3}{ }^{2-}\right]$, and calcium carbonate saturation state of the calcifying medium relative to seawater ${ }^{12-15}$.

In addition to regulating calcification site $\mathrm{pH}$ via proton pumping, organisms that perform both photosynthesis and calcification may also influence carbonate chemistry at the site of calcification via photosynthetic drawdown of dissolved inorganic carbon (DIC), DIC release via respiration, and/or proton release via calcification (i.e., $\mathrm{Ca}^{2+}+\mathrm{HCO}_{3}{ }^{-} \rightarrow \mathrm{H}^{+}+\mathrm{CaCO}_{3}$ ).

Coccolithophores are unicellular flagellate algae with the ability to produce calcite plates (coccoliths) within vesicles that they assemble in an interlocking fashion on the exterior surface of their cell wall. Coccolithophores inhabit tropical to subpolar environments throughout the ocean ${ }^{16,17}$. They are the most prolific producers of $\mathrm{CaCO}_{3}$ in the ocean, accounting for nearly half of global production ${ }^{18,19}$. Therefore, the coccolithophore response to elevated $p \mathrm{CO}_{2}$ is important from both ecological and global biogeochemical perspectives.

A recent study suggested that, on geological timescales, the combination of elevated dissolved $\mathrm{CO}_{2}$ and elevated total alkalinity (TA) supports the production of thicker coccoliths ${ }^{20}$. However, controlled laboratory experiments suggest that the coccolithophore calcification and photosynthesis response to elevated $p \mathrm{CO}_{2}$ is variable and complex, with disparate results observed amongst different species and even different strains of the same species $5,9,21,22$. It is possible that species- and strainspecific differences in coccolithophores' ability to regulate $\mathrm{pH}$ and carbonate chemistry at their site of calcification contributes to the variability in their responses to OA. However, few measurements of $\mathrm{pH}$ at the site of calcification within coccolithophores have been reported ${ }^{23}$, with none addressing the impact of elevated $p \mathrm{CO}_{2}$ on calcification site $\mathrm{pH}$.

Boron isotope ratios $\left(\delta^{11} \mathrm{~B}\right)$ in biogenic carbonates are used as a proxy for seawater $\mathrm{pH}$, based on the observation that seawater $\mathrm{pH}$ controls the $\delta^{11} \mathrm{~B}$ composition of dissolved borate, which is assumed to be the primary boron species incorporated into abiogenic and biogenic carbonates ${ }^{24}$. However, discrepancies observed between carbonate $\delta^{11} \mathrm{~B}$-derived $\mathrm{pH}$ and known seawater $\mathrm{pH}$ indicate that $\delta^{11} \mathrm{~B}$ compositions of biogenic carbonates may represent $\mathrm{pH}$ at the site of calcification, which may reflect biological control of $\mathrm{pH}$ at the site of calcification in some species, or seawater $\mathrm{pH}$ in other species, or some combination of seawater $\mathrm{pH}$ and biological control. This use of $\delta^{11} \mathrm{~B}$ as a proxy of calcification site $\mathrm{pH}$ has been most widely applied to scleractinian corals ${ }^{12,13,15,25,26}$, with only one study to date applying this approach to a species of coccolithophore (Emiliania huxleyi) ${ }^{27}$.

Previous studies have used fluorescent dyes to estimate cytosolic and coccolith vesicle $\mathrm{pH}$, and their sensitivity to changes in external seawater $\mathrm{pH}^{23,28}$. However, our approach adds new information because the coccolith $\delta^{11} \mathrm{~B}$ should reflect the $\mathrm{pH}$ of the coccolith-forming vesicle at the precise time and location of coccolith formation, rather than vesicle $\mathrm{pH}$ at the time of dye injection and imaging. Here, we also consider stable carbon isotope data from inorganic and organic portions of coccolithophores to gain insight into how coccolithophores utilize different species of DIC for both photosynthesis and calcification, since elevated atmospheric- $p \mathrm{CO}_{2}$ will change the distribution of DIC species in seawater.

Ochrosphaera neapolitana (O. neapolitana) is a mostly nonmotile coccolithophore species that is widely distributed along the coastal zone of the North Atlantic and Indian Oceans, Mediterranean Sea, and Japanese Current region ${ }^{29-31}$. This species has a unique mechanism for producing coccoliths, wherein the coccolith vesicle is formed at the periphery of the cell instead of adjacent to the nuclear membrane, as for Emiliania huxleyi (E. huxleyi), or between the nucleus and plasma membrane, as for Pleurochrysis carterae $^{29}$. Unlike the coccolithophore species E. huxleyi and genera Gephyrocapsa, Coccolithus, and Calcidiscus, which produce highly calcified placoliths, i.e., lith-structures with two or more well-developed shields, O. neapolitana produces more lightly calcified muroliths, i.e., lith-structures without welldeveloped shields ${ }^{29,32,33}$. The production of less calcified liths by O. neapolitana could be linked to a different strategy for allocating dissolved inorganic carbon resources under different environmental conditions.

Furthermore, it has been shown that $O$. neapolitana precipitates high-magnesium calcite, while the well-studied coccolithophore genera Emiliania and Gephyrocapsa produce low-magnesium calcite liths, providing further evidence that $O$. neapolitana calcifies in a different manner than other species of coccolithophores ${ }^{34}$. However, few studies have explored the allocation of dissolved inorganic carbon resources between photosynthesis and calcification within O. neapolitana (e.g., ref. ${ }^{35}$ ). For these reasons, along with the logistical need to culture large volumes of coccolithophores for measuring isotope ratios of lowabundance elements such as boron, the relatively fast-growing species $O$. neapolitana was used to develop our combined $\delta^{11} \mathrm{~B}$ and $\delta^{13} \mathrm{C}$ approach for constraining the response of calcifying fluid chemistry in coccolithophores to OA.

Here, we report on controlled laboratory experiments investigating the impact of $\mathrm{CO}_{2}$-induced $\mathrm{OA}$ on the calcifying fluid dynamics and utilization of DIC within the coastal coccolithophore species $O$. neapolitana. The effective $p \mathrm{CO}_{2}$ range examined spans $226 \pm 11 \mu \mathrm{atm}$ (glacial) to $521 \pm 19 \mu \mathrm{atm}$ (year 2070). We make inferences about this species' (1) ability to regulate calcifying fluid $\mathrm{pH}$ using boron isotopes as a proxy of calcifying fluid $\mathrm{pH},(2)$ utilization of carbon species in calcification and photosynthesis, using stable isotopes of carbon and oxygen, and (3) photosynthetic and calcification responses to $\mathrm{CO}_{2}$-induced $\mathrm{OA}$, using their PIC/POC ratio. Our results suggest that O. neapolitana maintains a constant $\mathrm{pH}$ at the site of calcification and can maintain relatively constant calcification-to-photosynthesis ratios across a range of seawater $\mathrm{pH}$ conditions by utilizing higher proportions of $\mathrm{CO}_{2}$ compared to $\mathrm{HCO}_{3}{ }^{-}$as seawater $\mathrm{pH}$ decreases.

\section{Results and Discussion}

Uptake of dissolved boron species by coccolithophores. The coccolith $\delta^{11} \mathrm{~B}$ values, fractionated from the culture medium $\delta^{11} \mathrm{~B}$ of $0.64 \%$, range from $-15 \%$ to $-25 \%$ o (Fig. 1 ). Although boron isotopic compositions of marine carbonates, such as corals and foraminifera, have been widely studied and applied as proxies for seawater or calcification site $\mathrm{pH}$ (e.g., refs. ${ }^{12,15,25,36,37}$ ), the $\delta^{11} \mathrm{~B}$ composition of coccolithophore calcite has not been well-constrained. Non-charged boric acid has been shown to travel across the cell membranes of plants via diffusion, a process that discriminates against the positively charged borate ion ${ }^{38,39}$. Therefore, Stoll et al. ${ }^{40}$ hypothesized that boric acid enters coccolithophore cells exclusively through a similar mechanism, given the relatively high concentration of boron in seawater compared to freshwater. In contrast, the boron isotopic composition of 


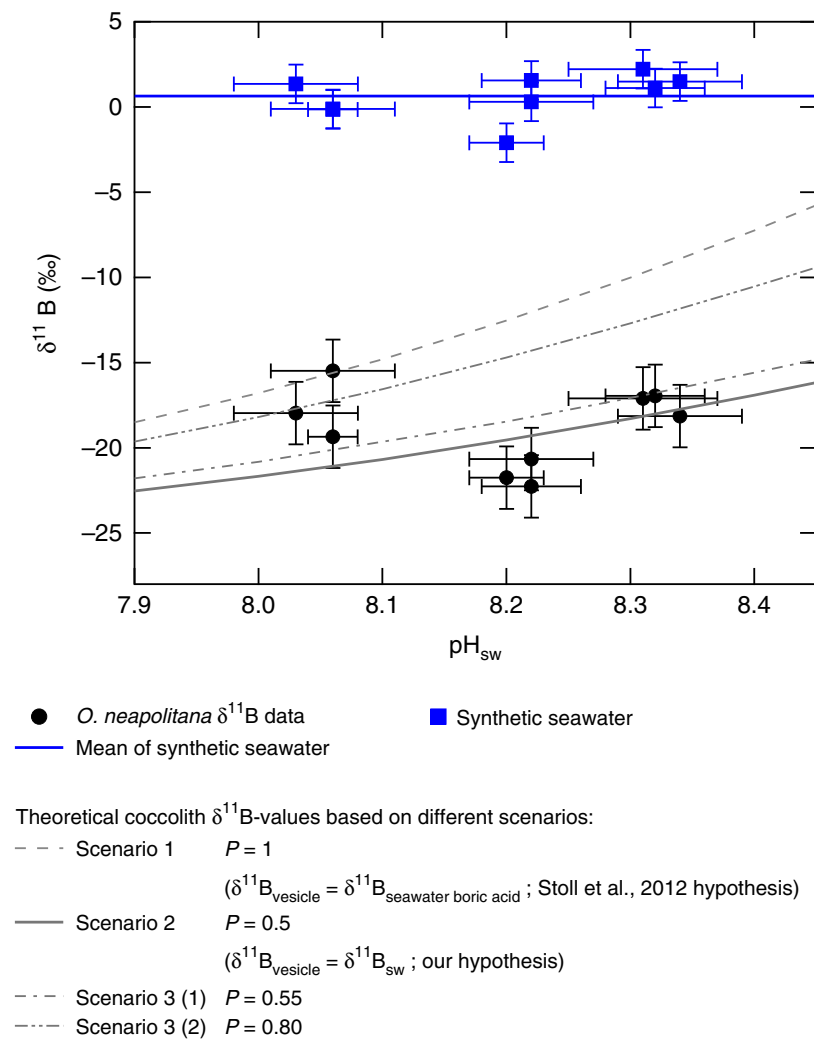

Fig. 1 Impact of transporting different boron species to calcification site on coccolith boron isotopic composition. The relationship between $\delta^{11} \mathrm{~B}$ and $\mathrm{pH}_{\mathrm{sW}}$ for three B-transport scenarios (gray dash line, gray solid line, gray dash-dot line, and gray dash-double dots line for scenarios 1, 2, 3(1), and $3(2)$, respectively) are compared to $\delta^{11} \mathrm{~B}-\mathrm{pH}_{\mathrm{sW}}$ relationships for coccoliths from the present study (solid black circles). The B-transport scenarios were calculated relative to average $\delta^{11} \mathrm{~B}$ of culture seawater (blue line is average $\delta^{11} \mathrm{~B}$ of culture seawater across treatments). $P$ is defined as the proportion of total boron entering the calcifying vesicle as boric acid. Individual culture seawater $\delta^{11} \mathrm{~B}$ results are shown as solid blue squares. Although the different B-transport scenarios assume different proportions of seawater boric acid and borate are transported to the coccolith calcifying vesicle, all scenarios assume that the $B$ species will be redistributed in the vesicle pursuant to vesicle $\mathrm{pH}$. The models also assume that only borate ion is incorporated into the coccolith calcite. Scenario 2, boric acid and borate enter calcifying vesicle in proportions that exist in seawater, such that $\delta^{11} \mathrm{~B}_{\text {vesicle }}={ }^{11} \mathrm{~B}_{\mathrm{sw}}$, best describes the $\delta^{11} \mathrm{~B}-\mathrm{pH}_{\mathrm{sw}}$ relationships for coccoliths from the present study (gray solid line). Deviations from the scenario 2 curve occur under the most acidified treatment, which may reflect biological elevation of $\mathrm{pH}$ at the site of calcification. Error bars are 2 SD for $y$-axis and 1 SD for $x$-axis. See detailed calculation in Supplementary Note 1

many marine biogenic carbonate archives has been found to reflect calcification site $\mathrm{pH}^{12,13,15,25,26}$, supporting the hypothesis that $\delta^{11} \mathrm{~B}$ of total boron within the parent fluids of calcification is identical to that of seawater, and that only borate ion is incorporated in these carbonates. Because questions remain as to the source(s) and pathway(s) of inorganic boron into coccolithophores, we discuss the compatibility of the results of the present study with three potential boron-uptake scenarios: (1) only boric acid can penetrate the coccolithophore cell membrane to the calcification site, yielding total boron $\delta^{11} \mathrm{~B}$ at the calcification site highly enriched relative to ambient seawater; (2) boric acid and borate penetrate the cell membrane in proportions equivalent to their abundance in seawater, yielding total boron $\delta^{11} \mathrm{~B}$ at the calcification site identical to ambient seawater; and (3) an intermediate scenario in which both seawater boric acid and borate ion penetrate the cell membrane to the site of calcification, but with higher boric acid:borate ratios than in the ambient seawater-thereby yielding total boron $\delta^{11} \mathrm{~B}$ at the calcification site slightly enriched relative to ambient seawater.

In the first scenario, if only boric acid enters the coccolithophore cell, $\delta^{11} \mathrm{~B}$ of total $\mathrm{B}$ at the calcification site will be about $5-10 \%$ higher than that of the culture seawater across the range of $\mathrm{pH}$ investigated in this study. Thus, assuming that no further fractionation of boron isotopes occurs throughout the calcification process and only borate ion is incorporated into coccolith calcite, the coccolith $\delta^{11} \mathrm{~B}$ value should also be about $5-10 \%$ o higher than the theoretical borate curve for seawater (Fig. 1, gray dash line). In the second scenario, where boric acid and borate penetrate the cell membrane in proportions equivalent to their relative abundance in seawater, coccolith $\delta^{11} \mathrm{~B}$ value should follow the gray solid line in Fig. 1. Finally, for the third scenario (e.g., Fig. 1, gray dash-dot line and gray dash-double dots line), coccolith $\delta^{11} \mathrm{~B}$ value should fall between the gray dashed line and gray solid line in Fig. 1.

In the first scenario, the predicted borate $\delta^{11} \mathrm{~B}$ values (Fig. 1, gray dash line) are higher than most coccolith $\delta^{11} \mathrm{~B}$ measurements. If this was driven purely by calcification site $\mathrm{pH}$, the values could be explained by $O$. neapolitana downregulating their calcification site $\mathrm{pH}$ to $<7.9$, which would reduce the calcite saturation state and be relatively unfavorable for calcification.

In the second scenario, the predicted borate $\delta^{11} \mathrm{~B}$ values closely match the coccolith $\delta^{11} \mathrm{~B}$ measurements, especially for $\mathrm{pH}$ above 8.15. Only under lower $\mathrm{pH}(\mathrm{pH}=8.05)$ do the coccolith $\delta^{11} \mathrm{~B}$ values deviate positively from the predicted borate $\delta^{11} \mathrm{~B}$ values (Fig. 2, gray solid line). This positive deviation can be explained by the maintenance of a constant and elevated $\mathrm{pH}$ in the calcification vesicle relative to seawater $\mathrm{pH}$, which has been observed in many other marine calcifying organisms (e.g., refs. ${ }^{15,41,42}$ ). This scenario has been widely adopted by researchers using $\delta^{11} \mathrm{~B}$ of biogenic carbonates as a proxy for calcification site $\mathrm{pH}$ in marine calcifying organisms ${ }^{12,13,15,25,26}$.

Alternatively, both boric acid and borate may be transported into the coccolith vesicle (scenario 3 ) but with the boric acid: borate ratio elevated compared to seawater. This latter scenario should be considered the least likely as the authors are aware of no mechanism for the partial discrimination against borate during boron uptake to the site of calcification and, if accurate, would constitute a hitherto unrecognized mechanism for boron transport in coccolithophores (see further discussion in Supplementary Note 1).

The scenario wherein the total boron $\delta^{11} \mathrm{~B}$ in the coccolith vesicle is equivalent to the total boron $\delta^{11} \mathrm{~B}$ in seawater (scenario 2) is most compatible with the results of the present study. This suggests that the active biological elevation of coccolith vesicle $\mathrm{pH}$ drives the offset in coccolith $\delta^{11} \mathrm{~B}$ from the theoretical borate $\delta^{11} \mathrm{~B}-\mathrm{pH}$ curve, which is apparent in the lowest $\mathrm{pH}$ treatment.

Coccolith $\boldsymbol{\delta}^{11} \mathrm{~B}$ as an indicator of calcifying vesicle $\mathrm{pH}$. Coccolith $\delta^{11} \mathrm{~B}$ was measured as a proxy for calcifying vesicle fluid $\mathrm{pH}$ in cultures bubbled with $\mathrm{CO}_{2}$-gas mixtures formulated at 280 , 400 , and 750 p.p.m., which resulted in average seawater $\mathrm{pH}$ values of $8.33,8.22$, and 8.05 in cultures. Based on calculations using the instrumental measurement of DIC and total alkalinity in the experimental treatments, the algal cultures were subjected to $p \mathrm{CO}_{2}$ levels of 226, 339, and $521 \mu \mathrm{atm}$ for the three treatments, with the difference between the nominal and effective $\mathrm{pCO}_{2}$ arising from incomplete mixing between the introduced gases and culture solutions and drawdown of aqueous $\mathrm{CO}_{2}$ by the coccolithophores. The average $\delta^{11} \mathrm{~B}$ of the total dissolved boron in the synthetic culture medium from individual tanks was $0.64 \pm$ 

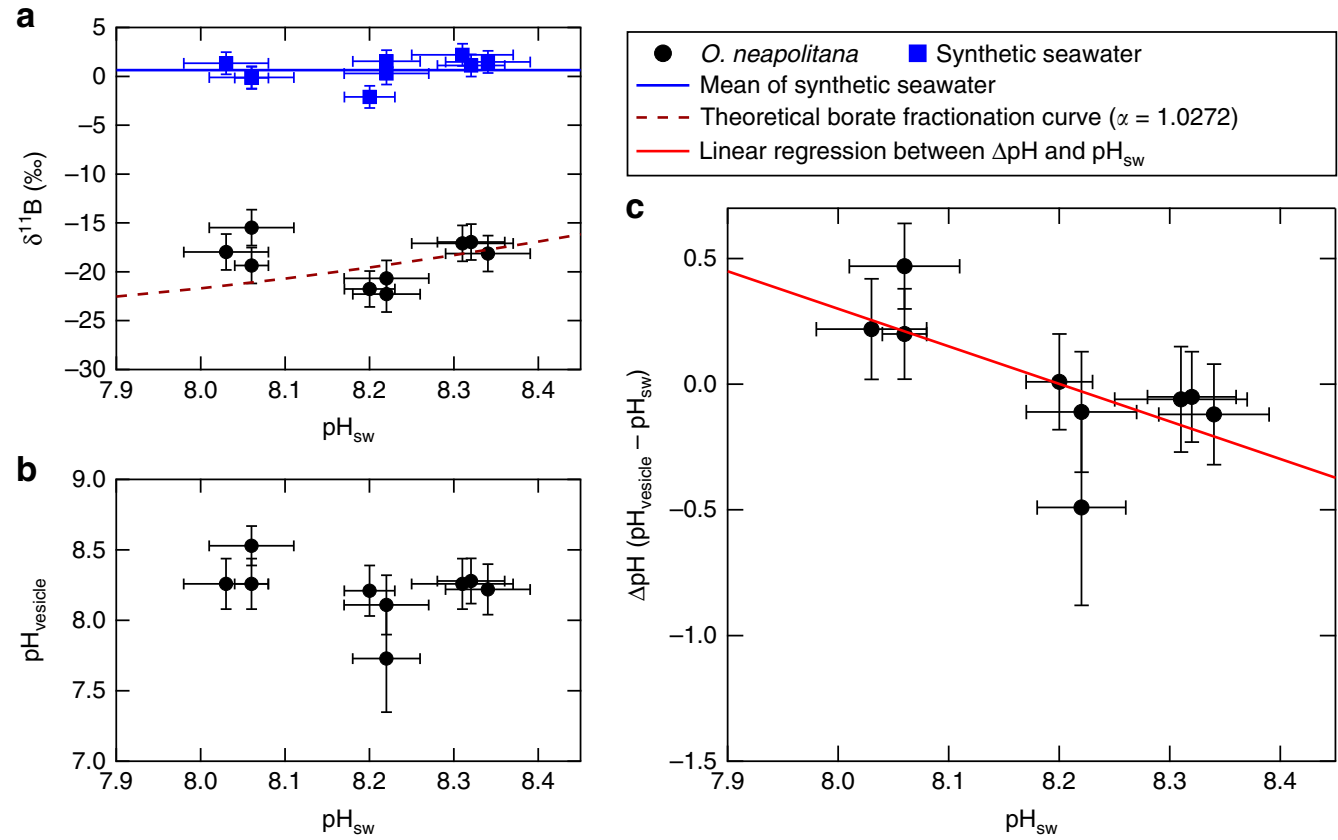

Fig. 2 Seawater $\mathrm{pH}$ vs. coccolith $\delta^{11} \mathrm{~B}$ and boron-isotope-inferred dynamics of calcifying vesicle $\mathrm{pH}$. a Seawater pH vs. $\delta^{11} \mathrm{~B}$ of coccolith calcite (solid black circles), $\delta^{11} \mathrm{~B}$ of culture seawater (solid blue squares; blue line is average $\delta^{11} \mathrm{~B}$ across treatments), and theoretical $\delta^{11} \mathrm{~B}$ of seawater borate (brown dash curve). If total boron $\delta^{11} \mathrm{~B}$ and $\mathrm{pH}$ of the seawater and calcifying vesicle are identical, and only borate is incorporated into the coccolith calcite, coccolith $\delta^{11} \mathrm{~B}$ results should lie on the theoretical $\delta^{11} \mathrm{~B}-\mathrm{pH}_{\mathrm{sw}}$ curve-which is not the case. Deviation from this relationship under the most acidified treatment is interpreted as reflecting biological elevation of $\mathrm{pH}$ at the site of calcification. $\mathbf{b}$ Seawater $\mathrm{pH}$ vs. coccolith vesicle $\mathrm{pH}$ inferred from $\delta^{11} \mathrm{~B}$ of coccolith calcite, and temperature, salinity, and $\delta^{11} \mathrm{~B}$ of seawater. c Seawater $\mathrm{pH}$ vs. offset between coccolith calcification site $\mathrm{pH}$ and culture seawater $\mathrm{pH}(\Delta \mathrm{pH})$. The linear regression between $\Delta \mathrm{pH}$ and seawater $\mathrm{pH}\left(\mathrm{pH}_{\mathrm{sw}}\right)$ is shown in red. Error bars are 2 SD for $y$-axis and 1 SD for $x$-axis

$1.30 \%$ o $(1 \sigma, n=9)$, about $39 \%$ o lower than natural seawater. Notably, the $\delta^{11} \mathrm{~B}$ of both boric acid $\left(\mathrm{B}(\mathrm{OH})_{3}\right)$, dominating at low $\mathrm{pH}$, and borate ion $\left(\mathrm{B}(\mathrm{OH})_{4}{ }^{-}\right)$, dominating at high $\mathrm{pH}$, are fractionated relative to $\delta^{11} \mathrm{~B}$ of total seawater boron as a function of solution $\mathrm{pH}^{24}$, with $\delta^{11} \mathrm{~B}$ of dissolved $\mathrm{B}(\mathrm{OH})_{4}{ }^{-}$increasing with increasing seawater $\mathrm{pH}$. Because only the $\mathrm{B}(\mathrm{OH})_{4}{ }^{-}$form of boron is thought to be incorporated into the calcite lattice (see discussion above $)^{24,40}, \delta^{11} \mathrm{~B}$ of coccolith calcite should represent $\delta^{11} \mathrm{~B}$ of dissolved $\mathrm{B}(\mathrm{OH})_{4}{ }^{-}$in the calcifying vesicle fluid. Assuming that $\delta^{11} \mathrm{~B}$ of total boron in the calcifying vesicle is inherited from the culture solution, then calcifying vesicle fluid $\mathrm{pH}$ can be estimated from the fractionation between $\delta^{11} \mathrm{~B}$ of total boron in the culture medium and $\delta^{11} \mathrm{~B}$ of coccolith calcite.

The observed difference in $\delta^{11} \mathrm{~B}$ between coccolith calcite, ranging from $-15 \%$ o to $-25 \%$, and culture medium, $0.64 \%$, yields a calcifying vesicle fluid $\mathrm{pH}$ between 7.7 and 8.5 , with a mean $\mathrm{pH}$ of 8.2 , based on calculations using the most widely applied boron fractionation factor ${ }^{43}$ (Fig. 2a, b).

In a previous study, Anning et al. ${ }^{23}$ used $\mathrm{pH}$-sensitive fluorescent dyes to detect coccolith vesicle $\mathrm{pH}$. They observed a bimodal distribution of calcifying vesicle $\mathrm{pH}$ within the population of cultured cells: one spanning $\mathrm{pH}$ 6.8-7.2 and the other spanning $\mathrm{pH} 7.6-8.3^{23}$. Although our study examines a different species of coccolithophore, the higher $\mathrm{pH}$ mode in the previous study ${ }^{23}$ is consistent with vesicle $\mathrm{pH}$ estimated from $\delta^{11} \mathrm{~B}$ data in the present study. Thus, the higher $\mathrm{pH}$ mode reported in the $\mathrm{pH}$ sensitive dye study, which is consistent with vesicle fluid $\mathrm{pH}$ estimated in the present study from coccolith $\delta^{11} \mathrm{~B}$ and thus representative of vesicle $\mathrm{pH}$ at the precise time and location of lith formation, may represent $\mathrm{pH}$ of vesicles that are actively engaged in lith production. In contrast, the lower $\mathrm{pH}$ mode may reflect $\mathrm{pH}$ of vesicles that are not actively forming liths.

Notably, no statistically significant $(p>0.05)$ correlation was observed between coccolith $\delta^{11} \mathrm{~B}$ and ambient seawater $\mathrm{pH}$, which is consistent with $\delta^{11} \mathrm{~B}$-based observations of calcifying vesicle $\mathrm{pH}$ for the coccolithophore E. huxleyi ${ }^{27}$. Instead, a significant negative trend was observed in the present study between seawater $\mathrm{pH}\left(\mathrm{pH}_{\mathrm{sw}}\right)$ and the offset $(\Delta \mathrm{pH})$ between vesicle $\mathrm{pH}$ $\left(\mathrm{pH}_{\text {vesicle }}\right)$ and $\mathrm{pH}_{\mathrm{sw}}\left(R^{2}=0.46, p<0.05\right)$ (Fig. $\left.2 \mathrm{c}\right)$. Together, these analyses suggest that vesicle $\mathrm{pH}$ is insensitive to changing $\mathrm{pH}_{\mathrm{sw}}$, and that increasing $\Delta \mathrm{pH}$ with decreasing $\mathrm{pH}_{\mathrm{sw}}$ reflects the algae's compensatory response to $\mathrm{OA}$, which maintains vesicle $\mathrm{pH}$ and carbonate chemistry favorable for coccolith formation even under increasingly acidic conditions. This response is distinct from the many types of calcifying marine organisms, including corals, foraminifera, and coralline algae, which show a clear decline in calcification site $\mathrm{pH}$ with decreasing seawater $\mathrm{pH}^{12-14,41,44}$. Therefore, these results suggest that this species of coccolithophore exerts an unusual degree of control over its calcification site $\mathrm{pH}$.

It has been suggested that photosynthesis can benefit calcification in several ways, including providing energy for proton pumping or other enzyme-driven ion exchange and generating hydroxyl ions that neutralize protons released via calcification ${ }^{45}$, thereby increasing calcium carbonate saturation state at the site of calcification. These mechanisms may assist coccolithophores in maintaining constant calcification site $\mathrm{pH}$ as ambient seawater $\mathrm{pH}$ declines, but only with commensurate increases in rates of photosynthesis, which is potentially supported by higher seawater DIC levels associated with elevated $\mathrm{pCO}_{2}{ }^{5}$.

Alternatively, calcification can also benefit photosynthesis by generating protons that increase seawater concentrations of aqueous $\mathrm{CO}_{2}$ and bicarbonate ion. Thus, elevated rates of calcification associated with constant $\mathrm{pH}$, inferred from coccolith $\delta^{11} \mathrm{~B}$, and elevated DIC, due to increased $p \mathrm{CO}_{2}$, at the site of calcification could also drive elevated rates of photosynthesis and result in constant $\mathrm{PIC} / \mathrm{POC}$ ratios, i.e., constant rates of calcification relative to organic matter production, across $p \mathrm{CO}_{2}$ treatments. 

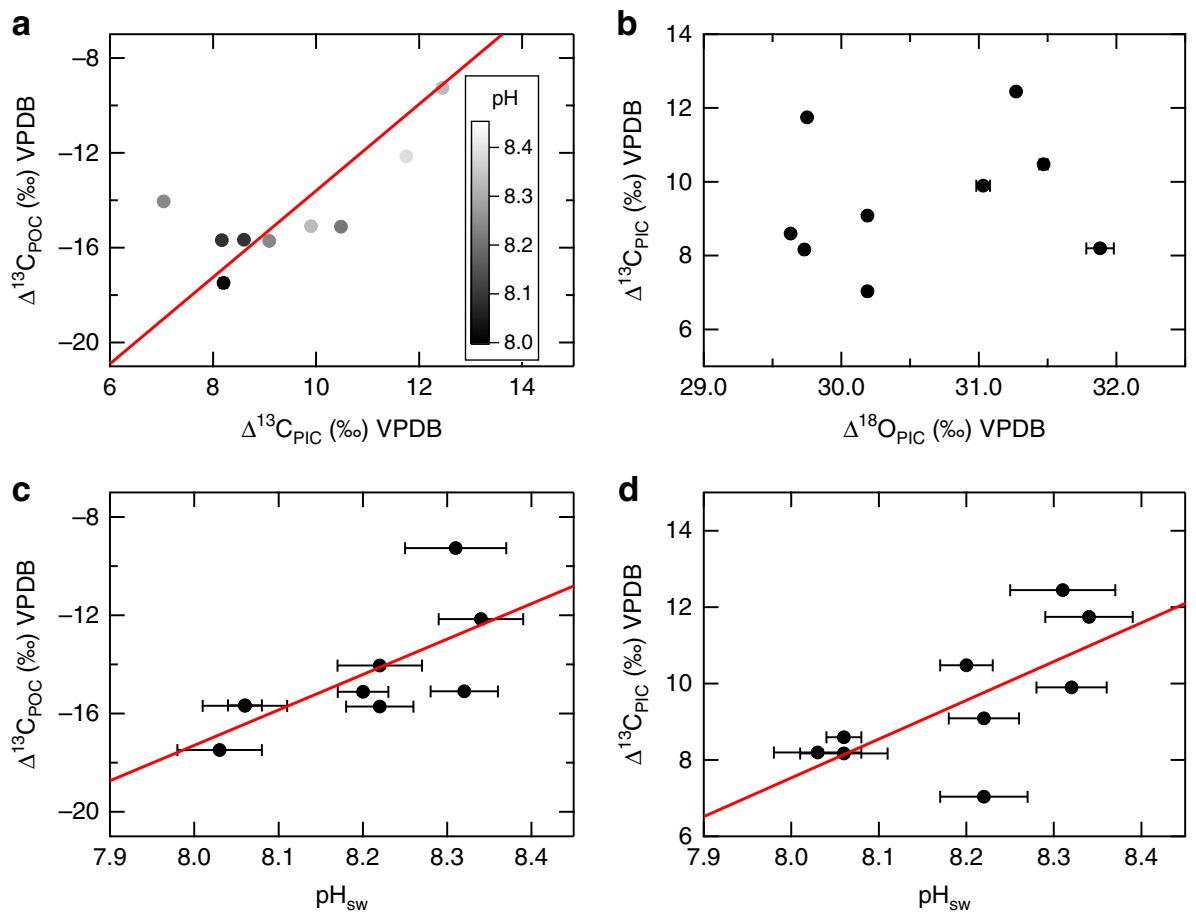

Fig. 3 Stable isotope of carbon and oxygen in O. neapolitana. Comparisons between the carbon isotopic compositions of particulate organic and inorganic carbon (a), the carbon and oxygen isotopic compositions of particulate inorganic carbon (b), seawater pH and the carbon isotopic composition of particulate organic carbon (c), and seawater $\mathrm{pH}$ and the carbon isotopic composition of particulate inorganic carbon (d). Red lines represent linear regression lines of each panel. Error bars are $1 \mathrm{SD}$

Stable carbon and oxygen isotopes within 0 . neapolitana. The $\delta^{13} \mathrm{C}_{\mathrm{PIC}}$ and $\delta^{13} \mathrm{C}_{\mathrm{POC}}$ range from $-20 \%$ to $5 \%$ and from $-45 \%$ to $-20 \%$, respectively. The introduction of different mixtures of compressed air and isotopically light compressed $\mathrm{CO}_{2}$ to the experimental treatments resulted in seawater DIC $\delta^{13} \mathrm{C}\left(\delta^{13} \mathrm{C}_{\text {DIC }}\right)$ being relatively depleted in the 226 and $521 \mu$ atm treatment. Therefore, stable carbon isotope analyses were normalized to $\delta^{13} \mathrm{C}_{\text {DIC }}$, such that $\delta^{13} \mathrm{C}_{\mathrm{PIC}}-\delta^{13} \mathrm{C}_{\mathrm{DIC}}=\Delta^{13} \mathrm{C}_{\mathrm{PIC}}$ and $\delta^{13} \mathrm{C}_{\mathrm{POC}}-$ $\delta^{13} \mathrm{C}_{\text {DIC }}=\Delta^{13} \mathrm{C}_{\text {POC }}$ (see Methods for details).

The normalized $\Delta{ }^{13} \mathrm{C}_{\mathrm{PIC}}$ and $\Delta^{13} \mathrm{C}_{\mathrm{POC}}$ range from $7 \%$ to $13 \%$ and from $-18 \%$ o to $-9 \%$, respectively, with $\Delta^{13} \mathrm{C}_{\mathrm{PIC}}$ consistently heavier than $\Delta^{13} \mathrm{C}_{\mathrm{POC}}$ by about $24 \%$, and with $\Delta^{13} \mathrm{C}_{\mathrm{PIC}}$ and $\Delta^{13} \mathrm{C}_{\mathrm{POC}}$ exhibiting positive correlation $\left(R^{2}=0.56, p=0.02\right.$; Fig. 3a). Both $\Delta^{13} \mathrm{C}_{\mathrm{PIC}}\left(R^{2}=0.47, p=0.04\right)$ and $\Delta^{13} \mathrm{C}_{\mathrm{POC}}\left(R^{2}=\right.$ $0.51, p=0.03)$ are also positively correlated with seawater $\mathrm{pH}$ (Fig. 3c, d). Coccolith $\delta^{18} \mathrm{O}\left(\delta^{18} \mathrm{O}_{\mathrm{PIC}}\right)$ range from $-3.5 \%$ to $-0.5 \%$. After normalizing to culture solution $\delta^{18} \mathrm{O}\left(\delta^{18} \mathrm{O}_{\mathrm{sw}}\right)$, $\Delta^{18} \mathrm{O}_{\text {PIC }}\left(\Delta^{18} \mathrm{O}_{\text {PIC }}=\delta^{18} \mathrm{O}_{\text {PIC }}-\delta^{18} \mathrm{O}_{\text {sw }}\right.$; VPDB (Vienna Pee Dee Belemnite)) ranges from 29.7 to $31.9 \%$, with no statistically significant correlation between $\Delta^{18} \mathrm{O}_{\mathrm{PIC}}$ and $\Delta^{13} \mathrm{C}_{\mathrm{PIC}}$, Fig. $3 \mathrm{~b}$.

Stable isotope results for both seawater and coccoliths were normalized to the VPDB scale, therefore, the reported $\Delta^{18} \mathrm{O}_{\mathrm{PIC}}$ values are about $30 \%$ higher than previously published analyses of coccolithophores normalized to SMOW (e.g., refs. ${ }^{10,46-49}$ ) (Fig. 4). Values of $\Delta^{13} \mathrm{C}_{\mathrm{POC}}$ and $\Delta^{13} \mathrm{C}_{\mathrm{PIC}}$ in the present study are also slightly higher than previously reported values for cultured coccolithophores, particularly for $\Delta^{13} \mathrm{C}_{\mathrm{PIC}}$, which is about $5-10 \%$ higher than previously published values ${ }^{10,48-50}$. This observed offset could be explained by differences in the experimental setup and/or species-and/or strain-specific carbon isotope fractionation.

Earlier work by Rickaby et al. ${ }^{10}$ and Hermoso et al. ${ }^{49}$ used $\mathrm{HCl}$ and $\mathrm{NaHCO}_{3}$ addition to manipulate seawater carbonate chemistry, while maintaining constant seawater $\mathrm{pH}$ in all treatments. Rost et al. ${ }^{51}$ and Hermoso ${ }^{48}$ used the acid-base addition method to recreate various seawater $\mathrm{pH}$ conditions, but with constant DIC. A ca. 3\%o variation in carbon isotope composition of coccolith calcite was observed for E. huxleyi cultured under similar $p \mathrm{CO}_{2}$ conditions, which Hermoso et al. ${ }^{49}$ attributed to different carbonate system parameters of the culture solutions arising from different modes of acidification, i.e., acid-base addition vs. $\mathrm{CO}_{2}$-bubbling, and other differences in experimental configuration. However, these factors should only account for $30-50 \%$ of the offset relative to prior studies in carbon isotopic compositions observed in the present study, suggesting that other factors are involved.

Species-specific differences in carbon isotope fractionation might also contribute to the differences observed between the present and past studies ${ }^{10,48,49}$. McClelland et al. ${ }^{52}$ proposed a model for evaluating potential sources of inorganic carbon for coccolithophores, as illustrated in Fig. 5b. The model predicts that coccolithophore species with lower PIC/POC ratios, such as $P$. placolithoides, will have a higher stable carbon isotopic composition in coccolith calcite under lower aqueous $\mathrm{CO}_{2}$ conditions due to increased flux of isotopically heavy carbon leaking from the chloroplast that is utilized in calcification and photosynthesis (Fig. 5c). This effect is predicted to decrease at higher- $\mathrm{CO}_{2}$ levels, which is consistent with the convergence between $O$. neapolitana $\delta^{13} \mathrm{C}$ and $\delta^{13} \mathrm{C}$ of other species cultured under higher- $\mathrm{CO}_{2}$ conditions. Although there are currently no published carbon isotope data for coccolithophores cultured at $p \mathrm{CO}_{2}<500 \mu \mathrm{atm}$, the McClelland model predicts a $\Delta^{13} \mathrm{C}_{\mathrm{PIC}}$ for P. placolithoides as high as $3 \%$ under $\left[\mathrm{CO}_{2(\mathrm{aq})}\right]$ of $\sim 5 \mu \mathrm{M}$. In summary, coccolithophores with different PIC/POC ratios should show species-specific carbon isotopic fractionation within the same $\left[\mathrm{CO}_{2(\mathrm{aq})}\right]$ range. Therefore, this model at least partially explains the larger carbon isotope fractionation observed in the present study.

Differences in acidification methods used in published experiments, i.e., acid-base addition vs. $\mathrm{CO}_{2}$-bubbling, which 

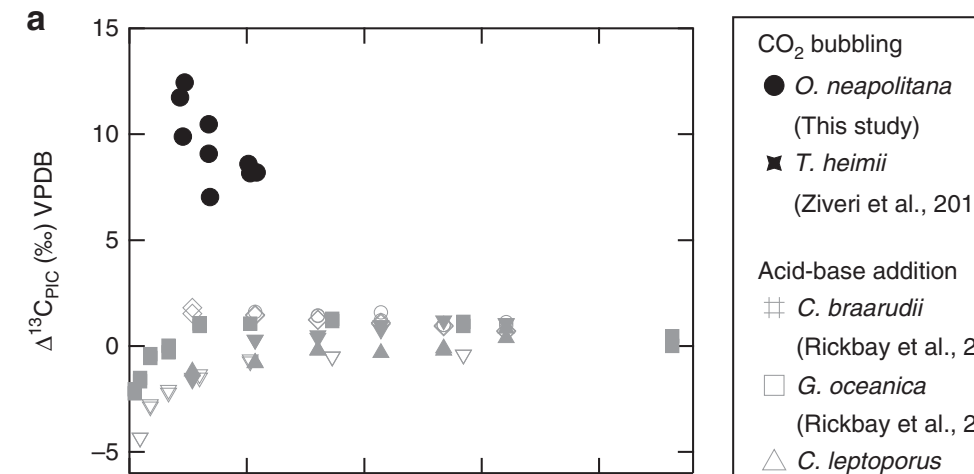

Acid-base addition

\# C. braarudii

(Rickbay et al., 2010)

$\square$ G. oceanica

(Rickbay et al., 2010)

$\triangle$ C. leptoporus

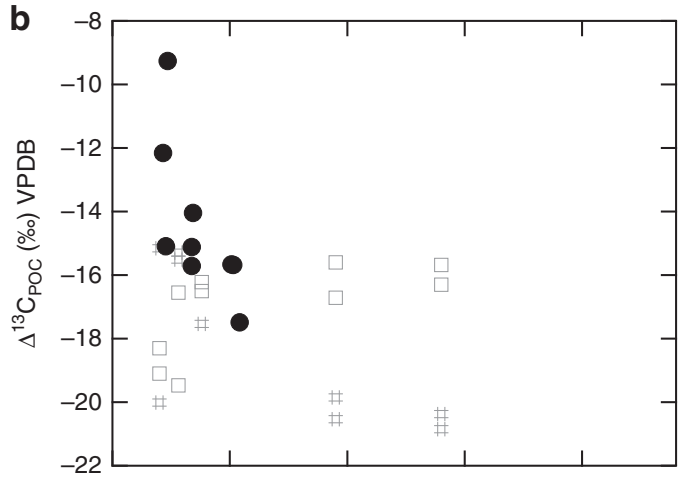

(Ziveri et al., 2012)

C. pelagicus

(Hermoso et al., 2015)

G. oceanica

(Hermoso et al., 2015)

E. huxleyi

(Hermoso et al., 2016)

P. placolithoides

(Hermoso et al., 2016)

$\triangle$ C. leptoporus

(Hermoso et al., 2016)

$\checkmark$ C. pelagicus

(Hermoso et al., 2016)

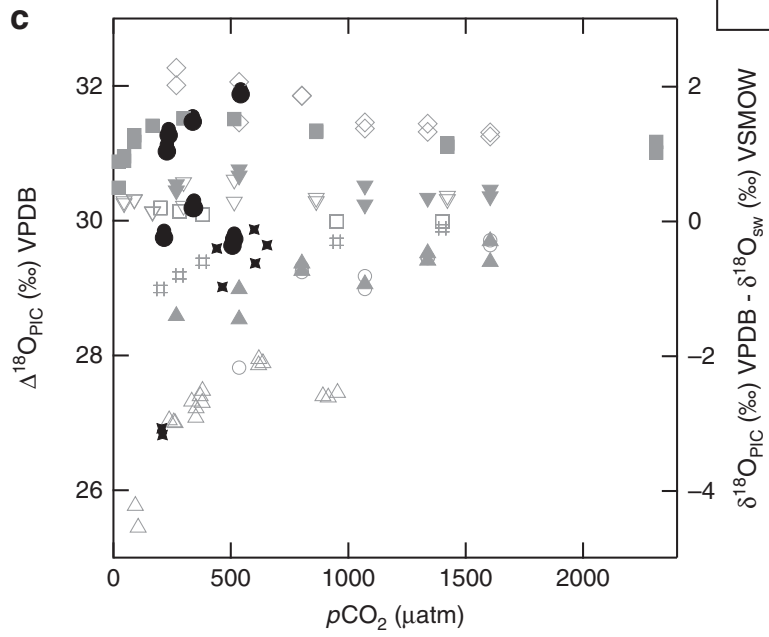

Fig. 4 Stable carbon and oxygen isotopes of O. neapolitana compared to other coccolithophore species. Atmospheric $p \mathrm{CO}_{2}$ vs. $\Delta^{13} \mathrm{C}_{\mathrm{PIC}}(\mathbf{a}), \Delta^{13} \mathrm{C}_{\mathrm{POC}}$ (b), and $\Delta^{18} \mathrm{O}_{\mathrm{PIC}}$ (c) for O. neapolitana (black solid circles) and other coccolithophore species. $\Delta^{18} \mathrm{O}_{\mathrm{PIC}}$ and most $\Delta^{13} \mathrm{C}_{\mathrm{POC}}$ data for $\mathrm{O}$. neapolitana fall within the range reported for other species, with $\Delta^{13} \mathrm{C}_{\mathrm{PIC}}$ being markedly higher. Offsets may be attributable to differences in species and/or method of acidification, as most past studies manipulate seawater $\mathrm{pH}$ via acid-base addition (labeled in gray), while the present study varied seawater $\mathrm{pH}$ via $\mathrm{CO}_{2}$ gas manipulation. Both the trends and absolute values of stable carbon and oxygen isotopes of $O$. neapolitana are compatible with the framework recently proposed by McClelland et al. ${ }^{52}$, as expanded on in Fig. 5 and the main text

results in differential DIC speciation may also explain the differing carbon isotope fractionation by coccolithophores shown in this study compared to prior studies. The present study acidified seawater in experimental treatments by sparging treatments with mixed gases formulated at different $p \mathrm{CO}_{2}$, which yielded a fixed $\mathrm{TA}$, elevated DIC, and reduced $\mathrm{pH}$. In contrast, acidifying the seawater treatments via acid addition decreases TA, DIC, and $\mathrm{pH}$. Thus, the two approaches yield different concentrations of total DIC and DIC speciation for equivalent seawater $\mathrm{pH}$ treatments. For the lowest $\mathrm{pH}$ treatments, the $\mathrm{CO}_{2}$-gas sparging method for acidification yields up to $50 \%$ higher concentrations of DIC than the acid-addition method of acidification. For the highest $\mathrm{pH}$ treatments, the $\mathrm{CO}_{2}$-gas sparging method of acidification maintains lower concentrations of $\mathrm{HCO}_{3}{ }^{-}$than the acid-base addition method. Therefore, the differential speciation of DIC between equivalent experimental treatments acidified using different methods combined with differences in the stable carbon isotopic composition of different DIC species could yield differences in coccolithophore $\Delta^{13} \mathrm{C}$ between the different experiments. Although this is unlikely to fully explain the $5-10 \%$ o higher stable carbon isotopic compositions in both organic and inorganic portions of O. neapolitana, the combination of these effects with species-level differences in carbon isotope fractionation may account for the observed discrepancies in $\Delta^{13} \mathrm{C}$ between the present and prior studies (e.g., refs. ${ }^{51,53}$ ).

The positive correlation between $\Delta^{13} \mathrm{C}_{\mathrm{PIC}}$ and $\Delta^{13} \mathrm{C}_{\mathrm{POC}}$ (Fig. 3a) suggests that the carbon sources for calcification and photosynthesis are primarily derived from the same internal DIC pool, 
a
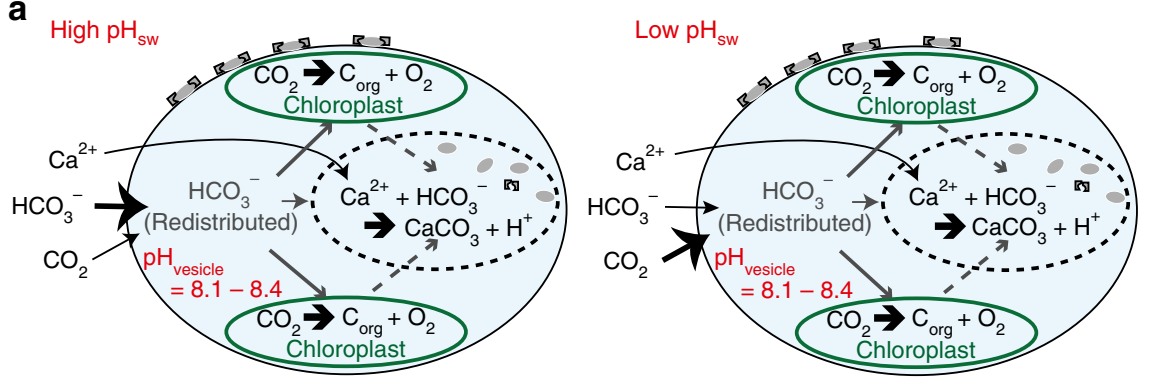

b
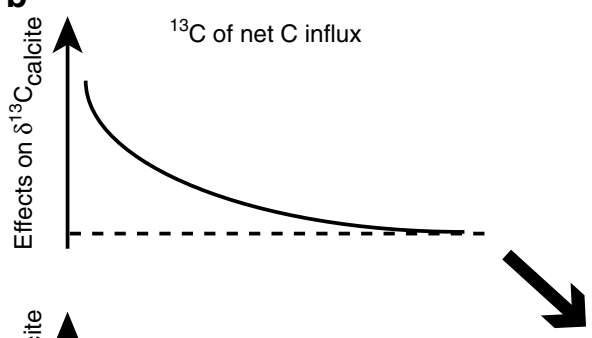

Low PIC/POC

coccolithophores

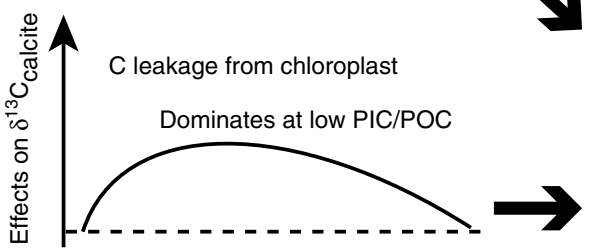

C
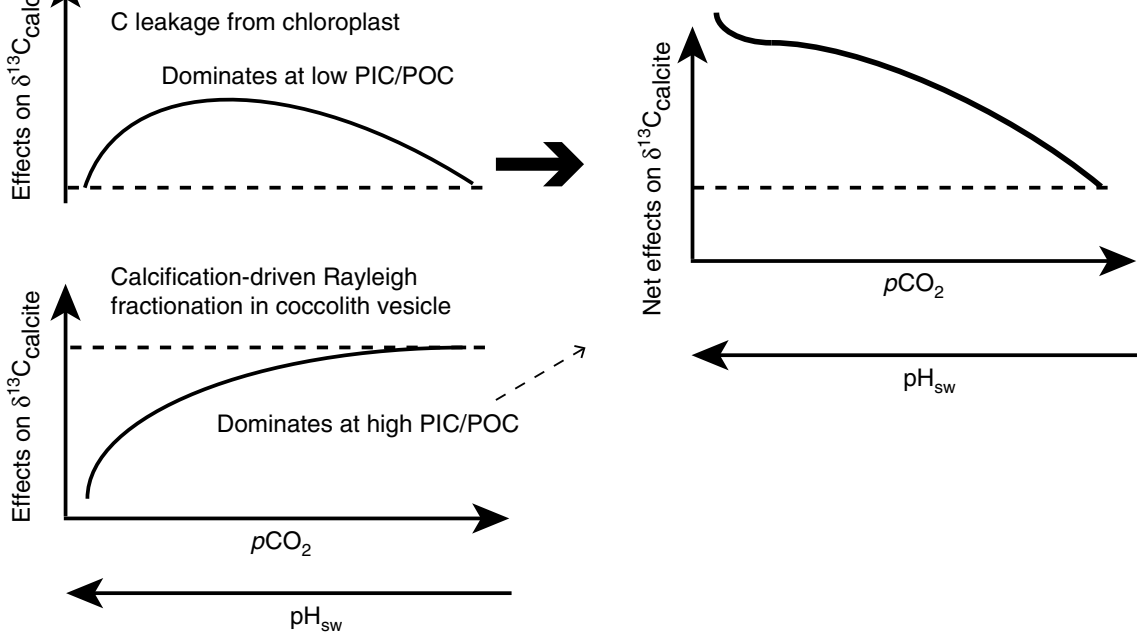

Fig. 5 Schematic illustrations of inorganic carbon uptake by O. neapolitana. a Illustration of inorganic carbon uptake model proposed in this study for O. neapolitana under high and low $\mathrm{pH}_{\mathrm{sw}}$ scenarios, which result in different proportions of $\mathrm{CO}_{2}$ to $\mathrm{HCO}_{3}{ }^{-}$entering the cell. We hypothesize that the changing $\delta^{13} \mathrm{C}$ of inorganic carbon influx (driven by a higher proportion of $\mathrm{CO}_{2}$ to $\mathrm{HCO}_{3}{ }^{-}$entering the cell under lower $\mathrm{pH}$ sw) dominates the carbon isotope fractionation recorded in $\mathrm{O}$. neapolitana. In both scenarios, coccolith vesicle $\mathrm{pH}$ is constant despite varying seawater $\mathrm{pH}$, as suggested by the relatively fixed boron isotope composition of the coccoliths formed over a range of seawater $\mathrm{pH}$. Notably, $\mathrm{pH}$ homeostasis in the calcifying vesicle and changing carbon supply are consistent with the lack of differences in growth rates across seawater treatments, as suggested by the lack of observable changes in PIC/POC ratio and size of coccoliths and coccospheres. b The individual effects of changing inorganic carbon influx, carbon leakage from chloroplast, and calcification-driven Rayleigh fractionation of the calcifying fluid on $\delta^{13} \mathrm{C}_{\mathrm{PIC}}$ (modified from McClelland et al. ${ }^{52}$ ). $\mathbf{c}$ The combined effects of changing inorganic carbon influx, carbon leakage from chloroplast, and calcification-driven Rayleigh fractionation of the calcifying vesicle fluid on $\delta^{13} C_{\mathrm{PIC}}$ in low PIC/ POC coccolithophore species. Note that the calcification-driven Rayleigh fractionation has a relatively small effect for low PIC/POC coccolithophores, as indicated by arrow size

and/or that the carbon sources for both processes exhibit the same response to changing seawater $\mathrm{pH}$. Both $\Delta^{13} \mathrm{C}_{\mathrm{PIC}}$ and $\Delta^{13} \mathrm{C}_{\mathrm{POC}}$ become about $6-10 \%$ lighter with the prescribed decrease in seawater $\mathrm{pH}$ and increase in seawater DIC. Hermoso et al. ${ }^{49}$ suggest that under elevated DIC, photosynthesis-driven Rayleigh fractionation of carbon isotopes may be diluted by the larger carbon pool, resulting in lower $\delta^{13} \mathrm{C}$ for $E$. huxleyi calcite. However, a decrease in $\delta^{13} \mathrm{C}$ with decreasing seawater $\mathrm{pH}$ was also observed for the organic portions of coccolithophores in the present study, and this cannot be explained by an increased DIC pool. It is therefore likely that other mechanisms control stable carbon isotopic fractionation within this species, at least for the organic portion of the algae.
Recent studies suggest that E. huxleyi has different $\mathrm{CO}_{2}$ and $\mathrm{HCO}_{3}{ }^{-}$influxes under different seawater $\mathrm{pH}$ conditions ${ }^{54,55}$. Although a different species was investigated in the present study, one explanation for the observed correlation between seawater $\mathrm{pH}$ and both $\Delta^{13} C_{\text {PIC }}$ and $\Delta^{13} C_{\text {POC }}$ is that the carbon sources for calcification and photosynthesis changed under acidified conditions, potentially because more $\mathrm{CO}_{2}$ was transported across the cell membrane compared with $\mathrm{HCO}_{3}{ }^{-}$. When $\mathrm{pH}$ decreases from 8.5 to $7.9, \delta^{13} \mathrm{C}$ of different DIC species will be $1 \%$ lighter due to the re-partitioning of species in the DIC system ${ }^{56}$. Additionally, assuming equilibrium isotope fractionation, $\delta^{13} \mathrm{C}$ of $\mathrm{CO}_{2(\mathrm{aq})}$ is about $9 \%$ lower than that of $\mathrm{HCO}_{3}{ }^{-}$for the same $\delta^{13} \mathrm{C}_{\mathrm{DIC}}$ at $25^{\circ} \mathrm{C}$ and $35 \mathrm{PSU}^{56}$. The $\mathrm{CO}_{2}$ gradient across the coccolithophore 
cell membrane increases as $p \mathrm{CO}_{2}$ increases. Therefore, when a greater portion of $\mathrm{CO}_{2}$, compared with $\mathrm{HCO}_{3}{ }^{-}$, is transported across the cell membrane, the $\delta^{13} \mathrm{C}$ of the coccolithophore internal DIC pool will decrease. Thus, the observed correlation between seawater $\mathrm{pH}$ and both $\Delta^{13} \mathrm{C}_{\mathrm{PIC}}$ and $\Delta^{13} \mathrm{C}_{\mathrm{POC}}$ is consistent with the hypothesis that substantially more $\mathrm{CO}_{2}$ is taken into the internal DIC pool of O. neapolitana, which supplies carbon for both its calcification and photosynthesis, at lower seawater $\mathrm{pH}$.

Instead of (or in addition to) increasing $\mathrm{CO}_{2}$ influx, the observed depletion in ${ }^{13} \mathrm{C}$ with decreasing seawater $\mathrm{pH}$ can also be explained by reduced uptake of $\mathrm{HCO}_{3}{ }^{-}$in a higher DIC environment. In either case, more ${ }^{13} \mathrm{C}$-depleted inorganic carbon is incorporated into the internal DIC pool of O. neapolitana for calcification and photosynthesis, resulting in positive correlations between $\Delta^{13} \mathrm{C}_{\text {PIC }}$ and $\mathrm{pH}_{\mathrm{sw}}$, between $\Delta^{13} \mathrm{C}_{\mathrm{POC}}$ and $\mathrm{pH}_{\mathrm{sw}}$, and therefore between $\Delta^{13} \mathrm{C}_{\mathrm{PIC}}$ and $\Delta^{13} \mathrm{C}_{\mathrm{POC}}$. These carbon species are then redistributed in the algae's ${ }^{13} \mathrm{C}$-depleted internal medium and utilized for both calcification and photosynthesis. Assuming the two processes use DIC from the same internal pool, the inorganic and organic carbon isotopic compositions would fractionate relative to the same $\delta^{13} C_{\text {DIC }}$. However, a greater difference in $\Delta^{13} \mathrm{C}_{\mathrm{POC}}$ (ca. $8 \%$ ) was observed between the two end-member $p \mathrm{CO}_{2}$ treatments (226 and $\left.521 \mu \mathrm{atm}\right)$ compared to the end-member differences in $\Delta^{13} \mathrm{C}_{\mathrm{PIC}}(6 \%)$, suggesting that additional fractionation occurs within chloroplasts and/or calcification vesicles.

McClelland et al. ${ }^{52}$ hypothesized in a recent study that the $\delta^{13} \mathrm{C}$ composition of coccolith calcite is influenced by the $\delta^{13} \mathrm{C}$ composition of carbon entering the cell, leakage of carbon from chloroplasts, and Rayleigh-type fractionation of carbon isotopes in the calcifying vesicle. They proposed that the $\delta^{13} \mathrm{C}$ compositions of the carbon influx and carbon leakage from chloroplasts have stronger effects in coccolithophore species with lower PIC/ $\mathrm{POC}$ ratios. One explanation for the different magnitudes of $\mathrm{pH}$ induced offsets in $\Delta^{13} \mathrm{C}$ between the organic and inorganic portions of coccolithophores is that isotopically heavier carbon leaked from the chloroplast may partially compensate for the decline in $\delta^{13} \mathrm{C}$ resulting from the increasing $\mathrm{CO}_{2}$ influx. Otherwise, the 1:1 slope of the regression between $\Delta^{13} \mathrm{C}_{\mathrm{POC}}$ and $\Delta^{13} \mathrm{C}_{\text {PIC }}$ (slope $=1.01$ ) indicates that the pattern resulted from the change in $\delta^{13} \mathrm{C}$ composition of a single DIC pool that supplies carbon for both calcification and photosynthesis within the algae.

A carbonate ion effect on $\mathrm{CaCO}_{3} \quad \delta^{18} \mathrm{O}$ has been both hypothesized and observed in biominerals, such that $\mathrm{CaCO}_{3} \delta^{18} \mathrm{O}$ will decrease with increasing $\mathrm{pH}$ because of the resulting increase in concentration of $\mathrm{CO}_{3}{ }^{2-}$, which has a more depleted $\delta^{18} \mathrm{O}$ composition $^{57}$. This effect has been observed in foraminifera, corals $^{58}$, and coccolithophores ${ }^{47}$. However, the opposite trend, albeit weak $(p>0.05)$, was observed between $\delta^{18} \mathrm{O}$ of $O$. neapolitana coccolith calcite and culture seawater $\mathrm{pH}$ in the present study, with coccolith $\delta^{18} \mathrm{O}$ increasing by ca. $2 \%$ as $\mathrm{pH}$ increased from 8.0 to 8.3. This may indicate that although inorganic carbon uptake changes under the different $p \mathrm{CO}_{2}$ treatments, the relative abundance of DIC species at the site of calcification is not significantly different due to active biological control of carbonate chemistry within the calcifying vesicle. Alternatively, the conditions of calcification within this species may not preserve isotopic fractionation that arises from DIC speciation in its calcifying fluid if, for example, mineral precipitation is too $\operatorname{slow}^{59}$ or if there is additional unconstrained biological fractionation affecting oxygen isotope compositions.

No PIC/POC changes in response to elevated $p \mathrm{CO}_{2}$. The particulate organic carbon (POC) and particulate inorganic carbon (PIC) content range from $11 \%$ to $34 \%$ and from $5 \%$ to $17 \%$,
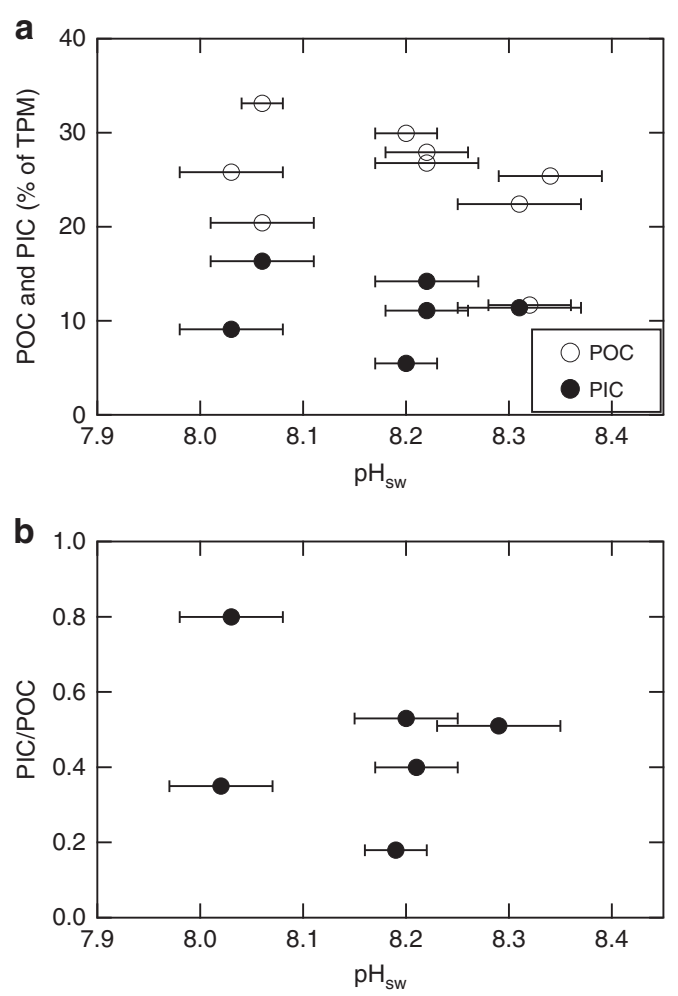

Fig. 6 PIC, POC, and PIC/POC of O. neapolitana for varying $\mathrm{pH}_{\mathrm{sW}}$. Seawater $\mathrm{pH}$ vs. particulate inorganic carbon (PIC) content as weight percent of total particulate matter (TPM) (solid circle, a), particulate organic carbon (POC) content as weight percent of TPM (open circle, a), and PIC/POC ratio (b). Error bars are $1 \mathrm{SD}$

respectively, of the coccolithophore total particulate matter (TPM) weight (Fig. 6a). The PIC/POC ratios range from 0.18 to 0.80 (mean $\pm 1 \sigma=0.46 \pm 0.21 ; n=6$ ). No statistically significant trend was observed between $\mathrm{pH}$ and either PIC $(p=0.80)$ or POC $(p=$ 0.29 ) content, or the PIC/POC ratio $(p=0.70)$ (Fig. $6 \mathrm{~b}$ ).

The lack of correlation between ambient $\mathrm{pH}_{\mathrm{sw}}$ and $\mathrm{PIC}, \mathrm{POC}$, or PIC/POC suggests that O. neapolitana does not change the proportions of DIC allocated for calcification and photosynthesis with increasing $p \mathrm{CO}_{2}$. Although there are no previously published PIC/POC ratios for O. neapolitana, this result has been observed in the coccolithophore species Pleurochrysis carterae, which also precipitates high-Mg calcite ${ }^{6,34}$. Casareto et al. ${ }^{6}$ observed increases in both PIC and POC in cultures at $1200 \mu \mathrm{atm} p \mathrm{CO}_{2}$ and at ambient $p \mathrm{CO}_{2}$ after 7 days of growth. However, higher production of POC than PIC yields PIC/POC ratios that are lower than the $\mathrm{PIC} / \mathrm{POC}$ ratio in the beginning of the experiment for both $p \mathrm{CO}_{2}$ treatments, but no significant difference between the two $p \mathrm{CO}_{2}$ treatments. The similar PIC/ POC trends when $\mathrm{pH}$ deceases in the two high $\mathrm{Mg} / \mathrm{Ca}$ coccolith species suggest that coccolithophores with high $\mathrm{Mg} / \mathrm{Ca}$ ratios may have different mechanisms for controlling the allocation of inorganic carbon for photosynthesis and calcification from other low-Mg coccolithophore species. For instance, it was previously hypothesized that coccolithophore species producing high-Mg calcite $(\mathrm{mMg} / \mathrm{Ca}>0.4)$ in modern seawater with elevated $\mathrm{Mg} / \mathrm{Ca}$ ratio $(\mathrm{mMg} / \mathrm{Ca}=5.2)$, which favors the abiotic precipitation of high-Mg calcite over low-Mg calcite $(\mathrm{mMg} / \mathrm{Ca}<0.4)$, have less control over the ionic composition of their calcifying medium than coccolithophores that produce low-Mg calcite in seawater favoring the precipitation of high-Mg calcite ${ }^{60}$.

Strontium isotope ratios of coccoliths (Supplementary Note 2 and Supplementary Fig. 1) also show no variation across $\mathrm{pH}$ 
a

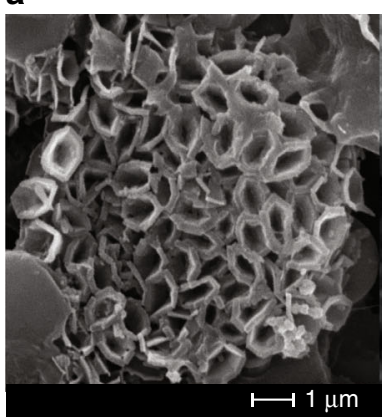

b

C

$\mathrm{pH}=8.34$

$\mathrm{pH}=8.22$

$\mathrm{pH}=8.08$

Fig. 7 Scanning electron images of typical O. neapolitana coccolithophores from the three $\mathrm{pCO}_{2}$ treatments. Electron images do not reveal differences in sizes of coccoliths and coccospheres under different $\mathrm{PCO}_{2}$ treatments. The effective culture seawater pH values are (a) 8.34, (b) 8.22, and (c) 8.08. Scale bars are $1 \mu \mathrm{m}$ in all images

treatments. Stevenson et al. ${ }^{61}$ identified a correlation between coccolithophore growth rate (co-varying with temperature) and coccolith $\delta^{88 / 86} \mathrm{Sr}$ for the species E. huxleyi, Coccolithus pelagicus spp. braarudii, and Gephyrocapsa oceanica. The lack of a statistically significant difference in $\delta^{88 / 86} \mathrm{Sr}$ between $\mathrm{pH}$ treatments in the present experiment on $O$. neapolitana is consistent with the observation that $\mathrm{PIC} / \mathrm{POC}$ ratios are invariant across $\mathrm{pH}$ treatments.

Scanning electron microscopy images of coccoliths. Imaging of coccoliths via scanning electron microscopy (SEM) does not reveal any gross changes in diameter or thickness of the individual coccoliths or of the diameter of the coccolithophore sphere as a whole (Fig. 7). Coccolithophore spheres are about 6-8 $\mu \mathrm{m}$ in all treatments, which is consistent with size ranges previously reported for these species ${ }^{29}$. The consistent size of coccoliths observed via SEM, the constant PIC/POC ratios, and the boron isotope results support the assertion that calcification, relative to organic matter production, within O. neapolitana is unimpeded by elevated $p \mathrm{CO}_{2}$ due to maintenance of $\mathrm{pH}$ homeostasis at the alga's site of calcification.

Mechanisms for O. neapolitana adaptation to increasing $p \mathrm{CO}_{2}$. The results of the present study suggest that calcification and photosynthesis within the coccolithophore $O$. neapolitana utilize carbon from the same internal DIC pool (Fig. 5a). The preferential uptake of light isotopes by the rubisco enzyme during photosynthesis results in ca. 25\% offset between $\delta^{13} \mathrm{C}_{\mathrm{PIC}}$ and $\delta^{13} \mathrm{C}_{\mathrm{POC}}$ in this species. When seawater DIC increases as a result of increasing atmospheric-p $\mathrm{CO}_{2},{ }^{13} \mathrm{C}$ becomes depleted in the internal DIC pool either through increased uptake of dissolved $\mathrm{CO}_{2}$ and/or decreased uptake of $\mathrm{HCO}_{3}{ }^{-}$, thereby decreasing both $\delta^{13} \mathrm{C}_{\mathrm{PIC}}$ and $\delta^{13} \mathrm{C}_{\mathrm{POC}}$. The observation that coccolith $\delta^{11} \mathrm{~B}$ remains constant across a range of seawater $\mathrm{pH}$ suggests that $O$. neapolitana maintains a fixed $\mathrm{pH}$ at the site of calcification across this range of seawater $\mathrm{pH}$. This enables the coccolithophores to continue producing coccoliths under lower $\mathrm{pH}$ and higher DIC conditions. Additionally, PIC, POC, and PIC/POC ratio were statistically invariant under all $p \mathrm{CO}_{2}$ conditions, indicating that $O$. neapolitana maintained similar rates of calcification, relative to rates of photosynthesis, irrespective of $p \mathrm{CO}_{2}$ treatment, even though the energetic cost of calcification is likely increasing with declining seawater $\mathrm{pH}$. Furthermore, SEM imaging reveals that coccoliths formed under the high- $p \mathrm{CO}_{2}$ treatments were similar in size and shape to coccoliths formed in the control and low- $p \mathrm{CO}_{2}$ treatments. These results are consistent with prior studies showing that some species of coccolithophores are able to maintain relatively constant ratios of calcification-to-photosynthesis under conditions of elevated $\mathrm{pCO}_{2}{ }^{5,9,62}$. The present study shows that some species of coccolithophores achieve this by maintaining $\mathrm{pH}$ homeostasis at the site of calcification and by utilizing a greater proportion of the isotopically lighter $\mathrm{CO}_{2}$ species of DIC for both photosynthesis and calcification.

\section{Methods}

Culture conditions and seawater carbonate chemistry. The coccolithophore $O$. neapolitana was cultured in a synthetic seawater medium made from a commercial sea salt mixture (Instant Ocean Sea Salt ${ }^{63}$ ) enriched with nutrients following the $F / 2$ recipe $^{64}$ from 11 January 2012 to 30 January 2012 at the University of North Carolina, Chapel Hill. Algal cultures were divided between three $p \mathrm{CO}_{2}$ treatments in triplicate aquaria, equilibrated with air- $\mathrm{CO}_{2}$ mixtures of 280,400 , and 750 p.p.m., selected to mimic levels before the industrial revolution, current atmospheric conditions, and levels predicted for year $2100 \mathrm{AD}$, resulting in seawater $\mathrm{pH}( \pm \mathrm{SE})$ of $8.05 \pm 0.01,8.22 \pm 0.01$, and $8.33 \pm 0.01$ and effective $\mathrm{pCO}_{2}$ $( \pm \mathrm{SE})$, calculated from measured DIC and TA, of $226 \pm 11,339 \pm 10$, and $521 \pm 19$. The nominal $280 \mu$ atm $p \mathrm{CO}_{2}$ gas was formulated by mixing compressed $\mathrm{CO}_{2}$ gas and compressed $\mathrm{CO}_{2}$-free air, the nominal $400 \mu$ atm $p \mathrm{CO}_{2}$ gas was compressed ambient air, and the nominal $750 \mu$ atm $\mathrm{pCO}_{2}$ gas was formulated by mixing compressed $\mathrm{CO}_{2}$ gas and compressed ambient air. Gases were mixed with Aalborg solenoid-valve-based mass flow controllers. The cultures were maintained at constant temperature $\left(25^{\circ} \mathrm{C}\right)$ and salinity (35 PSU) on a $16-8 \mathrm{~h}$ light-dark cycle in $38 \mathrm{l}$ glass aquaria with the same initial dose of coccolithophore cells $(\sim 400 \pm 40$ cell per l). The level and duration of the diurnal lighting cycle was based on Langer et al. ${ }^{9}$, Rickaby et al. ${ }^{10}$, Riebesell et al. ${ }^{21}$, Langer et al. ${ }^{62}$, Krug et al. ${ }^{65}$, and Zondervan et al. ${ }^{66}$ Temperature and salinity were based on the natural conditions of the source cultures. Nutrients in the experimental cultures were formulated pursuant to the $\mathrm{f} / 2$-si media, based upon Langer et al. ${ }^{9}$, Langer et al. ${ }^{62}$, Guillard and Ryther ${ }^{64}$, Krug et al. ${ }^{65}$, Zondervan et al. ${ }^{66}$, and Guillard ${ }^{67}$. Cultures were extremely dilute and collected at cell concentrations $<100,000$ cell per ml, which places culture growth well below the stationary phase ${ }^{34}$.

Temperature, salinity, and $\mathrm{pH}$ were measured every other day in the experimental tanks. For temperature measurements, a NIST (National Institute of Standards and Technology)-calibrated partial-immersion organic-filled glass thermometer (precision $\pm 0.3 \%$, accuracy $\pm 0.4 \%$ ) was used. A YSI 3200 conductivity meter with a YSI 3440 cell $(K=10)$ calibrated with seawater standards (A. Dickson, Scripps Institute of Oceanography) was used for salinity. Seawater $\mathrm{pH}$ was measured with an Orion 9156BNWP $\mathrm{pH}$ probe. The instrument was calibrated with two Orion NBS buffers (7.00 and 10.01) traceable to NIST standard reference material (for slope of the calibration curve) and with seawater standards of known $\mathrm{pH}$ (A. Dickson, Scripps Institute of Oceanography; for $y$-intercept of the calibration curve). Seawater DIC and TA were measured every week via coulometry (UIC 5400) and via closedcell potentiometric Gran titration calibrated with certified Dickson TA/DIC standards, respectively (see Supplementary Table 1 for seawater chemistry data). The certified reference materials (CRMs) were monitored during the measurements and the experimental seawater DIC and TA measurements were all corrected to the certified values of CRMs.

To determine seawater $p \mathrm{CO}_{2}, \mathrm{pH}$, carbonate ion concentration, $\left[\mathrm{CO}_{3}{ }^{2-}\right]$, bicarbonate ion concentration, $\left[\mathrm{HCO}_{3}^{-}\right]$, and aqueous $\mathrm{CO}_{2}$, the program CO2SYS ${ }^{68}$ was used with the inputs of weekly DIC and TA measurements and weekly average of temperature and salinity. The $\mathrm{K}_{1}$ and $\mathrm{K}_{2}$ carbonic acid constants from Roy et al. ${ }^{69}$, the stoichiometric aragonite solubility product from $\mathrm{Mucci}^{70}$, and an atmospheric pressure of 1.015 atm were applied in the program for the full seawater chemistry calculations (Supplementary Table 1). 
Although a short-term rise in $\mathrm{pH}$ was observed in all treatments during the last week of culturing (see Supplementary Note 3 and Supplementary Fig. 2 for carbonate chemistry of the culture media), all isotopic and PIC/POC data are compared to the experiment-long average of the calculated values of seawater $\mathrm{pH}$ $\left(\mathrm{pH}_{\mathrm{sw}}\right)$, which were stable throughout most of the experiment.

Coccolithophores were collected after 2 weeks of culturing, which yielded 10-15 generations of coccolithophores and ensured acclimation to the treatment conditions. The coccolithophores were filtered from the seawater, rinsed with $95 \%$ ethanol (95\% ethanol and 5\% deionized water), and stored in 95\% ethanol to prevent organic decay or dissolution. Additional culturing methods are provided in the supplementary materials.

Chemical pretreatments. Samples were cleaned and prepared for chemical analysis under class 10 laminar flow hoods in a class 10,000 clean room in the Glaciochemistry and Isotope Geochemistry Laboratory at the University of Michigan's Department of Earth and Environmental Sciences. About $10 \mu \mathrm{l}$ of the coccolithethanol mixture was set aside for SEM examination. Cleaning protocols and chemical pretreatments for isotopic analysis followed the methods of Barker et al. ${ }^{71}$ and Liu et al. ${ }^{72}$ Coccolithophore samples were rinsed three times with Super-Q (SQ) water (Millipore, $>18.2 \mathrm{M} \Omega \cdot \mathrm{cm}$ ) and then split three ways: $1.0-1.5 \mathrm{mg}$ of dry sample was allocated for total carbon (TC); 0.5-1.0 mg of dry sample was allocated for total organic carbon; and at least $2 \mathrm{mg}$ of dry sample was allocated for carbon, oxygen, boron, and strontium stable isotope analysis. Samples for TC and total organic carbon analysis were treated overnight with $2 \% \mathrm{HCl}$ to remove calcium carbonate and then were rinsed three times with SQ water. Samples for inorganic elemental and isotopic analysis were treated overnight with $10 \% \mathrm{H}_{2} \mathrm{O}_{2}$ buffered with $\mathrm{NaOH}$. After centrifugation and decanting of the solution, samples were rinsed with SQ water, $0.001 \mathrm{~N} \mathrm{HNO}_{3}$, and $\mathrm{SQ}$ water again to prevent recoil of organics or dust onto the samples. About $30-100 \mu \mathrm{g}$ of clean sample was prepared for inorganic $\delta^{13} \mathrm{C}$ and $\delta^{18} \mathrm{O}$ analyses. At least $1 \mathrm{mg}$ of cleaned sample was dissolved into $1.7 \mathrm{~N} \mathrm{HCl}$ for a target [B] of ca. 750 p.p.b.

Analysis of carbon and oxygen isotopes. TC was analyzed using a Costech ECS 4010 elemental analyzer in the Oceanography and Marine Geology Laboratory at the University of Michigan's Department of Earth and Environmental Sciences. Samples were weighed and wrapped in tin foil capsules for combustion. An acetanilide standard was used to calibrate carbon detection with respect to sample weight. Reproducibility in weight percent was $70.83 \pm 1.08 \%(1 \sigma, n=6)$.

Total organic carbon content and $\delta^{13} \mathrm{C}$ were analyzed at University of Michigan's Stable Isotope Laboratory on a Costech ECS 4010 elemental analyzer coupled to the inlet of a Finnigan Delta V Plus mass spectrometer operating in continuous flow mode. About 200-600 $\mu$ of organic coccolithophore sample was weighed in tin foil capsules. An acetanilide standard was used to calibrate organic carbon weight percent, and additional IAEA 600 caffeine and IAEA-CJ-6 sucrose standards were used to calibrate the organic $\delta^{13} \mathrm{C}$ analyses. The acetanilide standard measured $71.26 \%$ with a reproducibility of $0.95 \%(n=11)$. The organic $\delta^{13} \mathrm{C}$ for the acetanilide, IAEA 600 caffeine and IAEA-CJ-6 sucrose standards were measured as $-33.75 \pm 0.07 \% 0,-27.77 \pm 0.06 \%$, and $-10.45 \pm 0.05 \%$, respectively.

The $\delta^{13} \mathrm{C}$ and $\delta^{18} \mathrm{O}$ of coccolith calcite were analyzed with a Finnigan MAT Kiel IV carbonate preparation device coupled directly to the inlet of a Finnigan MAT 253 triple collector isotope ratio mass spectrometer in the Stable Isotope Laboratory at University of Michigan's Department of Earth and Environmental Sciences. The precisions of measurements were monitored with NBS 19 limestone standard $\left(\delta^{13} \mathrm{C}=1.96 \pm 0.07 \%\right.$ and $\left.\delta^{18} \mathrm{O}=-2.24 \pm 0.07 \% ; 1 \sigma, n=10\right)$. The $\delta^{18} \mathrm{O}$ of culture seawater was analyzed with a Picarro L2120-i Cavity Ringdown Spectrometer equipped with the A0211 high-precision vaporizer, autosampler, and ChemCorrect software at the University of Michigan Water Isotopes Lab. No water samples were preserved onsite for stable carbon analysis. The $\delta^{13} \mathrm{C}_{\mathrm{DIC}}$ values used for $\Delta^{13} \mathrm{C}_{\mathrm{POC}}$ and $\Delta^{13} \mathrm{C}_{\mathrm{PIC}}$ were based on measurements of seawater solutions that were formulated similarly to those used in the culture experiment. The $\delta^{13} \mathrm{C}_{\mathrm{DIC}}$ of seawater bubbled with compressed ambient air was $-5.90 \%$ o $\left(450 \mu\right.$ atm at $\left.30{ }^{\circ} \mathrm{C}\right)$ and $-6.67 \%$ o $\left(540 \mu \mathrm{atm}\right.$ at $\left.20^{\circ} \mathrm{C}\right)$. The $\delta^{13} \mathrm{C}_{\mathrm{DIC}}$ of seawater bubbled with mixtures of compressed ambient air and compressed $\mathrm{CO}_{2}$ was $-13.83 \%$ o $\left(750 \mu\right.$ atm at $\left.30^{\circ} \mathrm{C}\right)$ and $-15.69 \%$ o $\left(830 \mu\right.$ atm at $\left.20^{\circ} \mathrm{C}\right)$. The $\delta^{13} \mathrm{C}_{\text {DIC }}$ of the compressed $\mathrm{CO}_{2}$ gas was calculated from the above results using mass balance equations, and resulted in an average $\delta^{13} \mathrm{C}_{\text {DIC }}$ of $-29.09 \%$ for the compressed $\mathrm{CO}_{2}$ gas. The average $\delta^{13} \mathrm{C}_{\mathrm{DIC}}$ of the 20 and $30^{\circ} \mathrm{C}$ seawaters bubbled with compressed ambient air $(-6.29 \%)$ and the average $\delta^{13} \mathrm{C}_{\text {DIC }}$ of compressed $\mathrm{CO}_{2}$ gas $(-29.09 \%$ ) were then calibrated to $25^{\circ} \mathrm{C}$ and the $\mathrm{pH}$ of each treatment following the method described in Zeebe and Wolf-Gladrow ${ }^{56}$. The seawater $\delta^{13} \mathrm{C}_{\text {DIC }}$ values used in this study were calculated as $-28.98 \%$, $-6.29 \%$, and $-14.42 \%$ for water treated with mixture of compressed $\mathrm{CO}_{2}$ and compressed $\mathrm{CO}_{2}$-free air (low- $p \mathrm{CO}_{2}$ condition), compressed ambient air (present-day $p \mathrm{CO}_{2}$ condition), and mixture of compressed $\mathrm{CO}_{2}$ and compressed ambient air (high- $p \mathrm{CO}_{2}$ condition). Although this approach to estimating seawater $\delta^{13} \mathrm{C}_{\text {DIC }}$ may yield results that deviate slightly from direct measurements of seawater $\delta^{13} \mathrm{C}_{\mathrm{DIC}}$, it should not materially alter the trends in the carbon isotopic data, nor their interpretation. The seawater $\delta^{18} \mathrm{O}$ values were calibrated to VSMOW/VSLAP using three internal laboratory standards, with analytical precision $(1 \sigma)$ better than $0.1 \%$. To calculate $\Delta^{18} \mathrm{O}_{\mathrm{PIC}}\left(\Delta^{18} \mathrm{O}_{\mathrm{PIC}}=\delta^{18} \mathrm{O}_{\mathrm{PIC}}-\right.$ $\delta^{18} \mathrm{O}_{\mathrm{sw}}$ ), seawater $\delta^{18} \mathrm{O}$ was converted to VPDB scale with the relationship: $\delta^{18} \mathrm{O}_{\mathrm{VPDB}}=0.97001 \times \delta^{18} \mathrm{O}_{\text {VSMOW }}-29.99(\%)^{73,74}$.

All coccolith $\delta^{13} \mathrm{C}$ and $\delta^{18} \mathrm{O}$ results are reported relative to the VPDB standard:

$$
\begin{aligned}
& \delta^{13} \mathrm{C}=\left[\frac{\left({ }^{13} \mathrm{C} /{ }^{12} \mathrm{C}\right)_{\text {sample }}}{\left({ }^{13} \mathrm{C} /{ }^{12} \mathrm{C}\right)_{\mathrm{VPDB}}}-1\right] \times 1000(\%) \\
& \delta^{18} \mathrm{O}=\left[\frac{\left({ }^{18} \mathrm{O} /{ }^{16} \mathrm{O}\right)_{\text {sample }}}{\left({ }^{18} \mathrm{O} /{ }^{16} \mathrm{O}\right)_{\mathrm{VPDB}}}-1\right] \times 1000(\%)
\end{aligned}
$$

PIC/POC. Measurements and calculations of PIC and POC were made using standard procedures (e.g., refs. ${ }^{75,76}$ ). Coccolithophore samples from each treatment were dehydrated and weighed to determine their TPM weight. The particulate inorganic matter (PIM), i.e., $\mathrm{CaCO}_{3}$, in each sample was dissolved by addition of $2 \% \mathrm{HCl}$. Each sample was then re-weighed after removing the PIM, yielding the particulate organic matter (POM) weight. TC (\%) of the non-acidified samples and POC (\%) of the acidified samples were measured with a Costech Elemental Analyzer attached to an IRMS (the latter was used for carbon isotope measurements described in the carbon isotope methods section). Carbon-loss measurements were verified with acetanilide $(C=71.26 \mathrm{wt} \%)$ and atropine standards $(C=70.83 \mathrm{wt} \%)$. Each TC weight was calculated by multiplying TC (wt\%) by the TPM weight, and POC weight was calculated by multiplying the (wt\%) carbon in POM by the POM weight. PIC weight was then calculated as the difference between TC weight and POC weight. POC (wt\%) and PIC (wt\%) were then calculated by, respectively, dividing the POC and PIC weights by the TPM weight. The PIC/POC ratio was calculated by dividing PIC ( $w t \%)$ by POC (wt\%). Three of the calculated PICs (wt $\%$ ) were eliminated due to weak signal-to-noise ratios of their TC (wt\%) measurements.

Boron isotopes. The boron isotopic composition of both culture solution and coccolith samples were measured following the method of Liu et al. ${ }^{72}$ Briefly, samples were dissolved in $1.7 \mathrm{~N} \mathrm{HCl}$ to achieve a $[\mathrm{B}]=$ ca. 750 p.p.b. The microsublimation technique was used to separate boron from its matrix, which exploits boron's high volatility compared to other elements and organic compounds. About $50 \mu \mathrm{l}$ of dissolved sample solution was loaded onto the cap of a conical bottom Savillex $5 \mathrm{ml}$ vial. The vial was then closed and placed up-side down on a $65-70{ }^{\circ} \mathrm{C}$ patented extraction plate $\mathrm{e}^{77}$ for $12 \mathrm{~h}$. Boron isotopic analyses were conducted using a Thermo Fisher Triton PLUS multicollector thermal ionization mass spectrometer operating in negative ion mode for boron isotope analysis in the Glaciochemistry and Isotope Geochemistry Lab (GIGL) at the University of Michigan's Department of Earth and Environmental Sciences. Purified sample solution, $1 \mu \mathrm{l}$, was loaded onto an outgassed refilament after loading $1 \mu \mathrm{l}$ of boron-free seawater. Boron analyses were conducted using the total evaporation method ${ }^{78}$. Boron isotopic composition in seawater and coccolith samples were reported as $\delta^{11} \mathrm{~B}$, where

$$
\delta^{11} B=\left[\frac{\left({ }^{11} \mathrm{~B} /{ }^{10} \mathrm{~B}\right)_{\text {sample }}}{\left({ }^{11} \mathrm{~B} /{ }^{10} \mathrm{~B}\right)_{\text {SRM 951a }}}-1\right] \times 1000(\%)
$$

with ${ }^{11} \mathrm{~B} /{ }^{10} \mathrm{~B}$ for the boric acid standard SRM 951a is $4.0345 \pm 0.0084 \%$ o $(2 \sigma, n=$ $24)$. The reproducibility $(2 \sigma)$ of $\delta^{11} \mathrm{~B}$ in seawater and carbonate samples were 1.13 and $1.83 \%$, respectively ${ }^{79}$. A $\delta^{11} \mathrm{~B}-\mathrm{pH}$ transfer equation was used to calculate coccolith vesicle $\mathrm{pH}$ :

$$
\mathrm{pH}=p K_{\mathrm{b}}-\log \left(\frac{\delta^{11} \mathrm{~B}_{\mathrm{sw}}-\delta^{11} \mathrm{~B}_{\text {carbonate }}}{\alpha \delta^{11} \mathrm{~B}_{\text {carbonate }}-\delta^{11} \mathrm{~B}_{\mathrm{sw}}+1000(\alpha-1)}\right),
$$

where $p K_{\mathrm{b}}$ and $\alpha$ are the boron equilibrium constant and boron fractionation factor, respectively. The $p K_{\mathrm{b}}$ of each sample was calculated from average temperature and salinity of each replicate tank following the equation described by the US Department of Energy ${ }^{80}$, using an $\alpha$ of $1.0272^{43}$. Temperature, salinity, and total seawater boron $\delta^{11} \mathrm{~B}$ of each replicate tank were used to calculate calcifying vesicle $\mathrm{pH}$ in the different treatments.

The reproducibility of $\delta^{11} \mathrm{~B}$ in carbonate samples is about $1.8 \%$, which can be converted to about $0.18 \mathrm{pH}$ unit. Although this means that the $\delta^{11} \mathrm{~B}$ analyses cannot resolve $\mathrm{pH}$ variations within 0.18 units, it is sufficient to detect the potential change in coccolith $\delta^{11} \mathrm{~B}$ if coccolith $\delta^{11} \mathrm{~B}$ was simply responding to the prescribed 0.3 unit difference in seawater $\mathrm{pH}$ across the experimental treatments.

Scanning electron microscopy. SEM images of coccolithophores from different treatments were obtained with a Hitachi S3200N Scanning Electron Microscope at the University of Michigan's Electron Microbeam Analysis Laboratory and a Phenom G2 pro Scanning Electron Microscope at Roscoff Marine Station. For images obtained at the University of Michigan, dry coccolith pellets were mounted with carbon tape and coated with gold for at least $120 \mathrm{~s}$ to prevent static charging of their surface. A $15 \mathrm{kV}$ beam was applied to the samples with an $8 \mathrm{~mm}$ working distance. For images obtained at Roscoff Marine Station, samples were filtered on a membrane, which was then cut and mounted on the sample holder with carbon 
tape and imaged with a $10 \mathrm{kV}$ beam. SEM images were obtained with a resolution better than $1024 \times 800$

Radiogenic and stable Sr isotopes. Analyses of radiogenic and stable $\mathrm{Sr}$ isotopic followed the procedure described in Liu et al. ${ }^{79}$ Briefly, the residuals of coccolith samples after boron microsublimation were re-dissolved in $7 \mathrm{~N}$ nitric acid. $\mathrm{A}^{87} \mathrm{Sr}-$ ${ }^{84} \mathrm{Sr}$ double spike (spike:sample ratio $=1: 1$ ) was used to determine the stable strontium isotope composition of the culture medium and coccoliths. $\mathrm{Sr}$ was separated from other matrices by passing both unspiked and spiked samples through a 50-100 $\mu \mathrm{m}$ Sr-spec resin (Eichrom). About 100-200 ng and 200-250 ng of $\mathrm{Sr}$ in unspiked and spiked sample, respectively, were loaded on outgassed Resingle filament for $\mathrm{Sr}$ isotope analyses conducted on Thermo Fisher Triton PLUS multicollector thermal ionization mass spectrometer at the Glaciochemistry and Isotope Geochemistry Lab (GIGL) at the Department of Earth and Environmental Sciences, University of Michigan. To determine the Sr isotopic ratios and achieve within-run precision better than 10 p.p.m. (2 SE), a total of 400 cycles of data were collected for each measurement. The reproducibility of Sr isotopic standard SRM987 is $0.710246 \pm 13(2 \sigma, n=42)$. For direct comparisons to literature, all ${ }^{87} \mathrm{Sr} /$ ${ }^{86} \mathrm{Sr}$ data reported in this study were normalized to SRM987 $=0.710250$. The stable $\mathrm{Sr}$ data were reported as $\delta^{88 / 86} \mathrm{Sr}$, defined as:

$$
\delta^{88 / 86} \mathrm{Sr}=\left[\frac{\left(1^{88} \mathrm{Sr} /{ }^{86} \mathrm{Sr}\right)_{\text {sample }}}{\left(188 \mathrm{Sr} /{ }^{86} \mathrm{Sr}\right)_{\text {SRM } 987}}-1\right] \times 1000(11111)
$$

The reproducibility of $\delta^{88 / 86} \mathrm{Sr}$ values in the seawater standard IAPSO is $0.365 \pm$ $73 \%$ о $(2 \sigma, n=4)$ and in the inter-laboratory carbonate standard JCp-1 is $0.195 \pm$ $21 \%$ o $(2 \sigma, n=4)$.

Data availability. All results of the culture experiment and isotopic analyses are presented in the manuscript and Supplementary Table 1. The data is also available upon request from the corresponding authors.

Received: 3 July 2017 Accepted: 27 April 2018

Published online: 20 July 2018

\section{References}

1. Bednarsek, N. et al. Extensive dissolution of live pteropods in the Southern Ocean. Nat. Geosci. 5, 881-885 (2012).

2. Talmage, S. C. \& Gobler, C. J. Effects of past, present, and future ocean carbon dioxide concentrations on the growth and survival of larval shellfish. Proc. Natl. Acad. Sci. USA 107, 17246-17251 (2010).

3. Anthony, K. R. N., Kline, D. I., Diaz-Pulido, G., Dove, S. \& Hoegh-Guldberg O. Ocean acidification causes bleaching and productivity loss in coral reef builders. Proc. Natl. Acad. Sci. USA 105, 17442-17446 (2008).

4. Ries, J. B., Cohen, A. L. \& McCorkle, D. C. Marine calcifiers exhibit mixed responses to $\mathrm{CO}_{2}$-induced ocean acidification. Geology 37, 1131-1134 (2009).

5. Iglesias-Rodriguez, M. D. et al. Phytoplankton calcification in a high- $\mathrm{CO}_{2}$ world. Science 320, 336-340 (2008).

6. Casareto, B. E., Niraula, M. P., Fujimura, H. \& Suzuki, Y. Effects of carbon dioxide on the coccolithophorid Pleurochrysis carterae in incubation experiments. Aquat. Biol. 7, 59-70 (2009).

7. Fitzer, S. C., Phoenix, V. R., Cusack, M. \& Kamenos, N. A. Ocean acidification impacts mussel control on biomineralisation. Sci. Rep. 4, 6218 (2014).

8. Castillo, K. D., Ries, J. B., Bruno, J. F. \& Westfield, I. T. The reef-building coral Siderastrea siderea exhibits parabolic responses to ocean acidification and warming. Proc. R. Soc. Lond. B Biol. Sci. 281, https://doi.org/10.1098/ rspb.2014.1856 (2014).

9. Langer, G., Nehrke, G., Probert, I., Ly, J. \& Ziveri, P. Strain-specific responses of Emiliania huxleyi to changing seawater carbonate chemistry. Biogeosciences 6, 2637-2646 (2009).

10. Rickaby, R. E. M., Henderiks, J. \& Young, J. N. Perturbing phytoplankton: response and isotopic fractionation with changing carbonate chemistry in two coccolithophore species. Clim. Past 6, 771-785 (2010).

11. Fiorini, S., Middelburg, J. J. \& Gattuso, J.-P. Testing the effects of elevated $\mathrm{pCO}_{2}$ on coccolithophores (Prymnesiophyceae): comparison between haploid and diploid life stages. J. Phycol. 47, 1281-1291 (2011).

12. Trotter, J. et al. Quantifying the $\mathrm{pH}$ 'vital effect' in the temperate zooxanthellate coral Cladocora caespitosa: validation of the boron seawater $\mathrm{pH}$ proxy. Earth Planet Sci. Lett. 303, 163-173 (2011).

13. Allison, N., Cohen, I., Finch, A. A., Erez, J. \& Tudhope, A. W. Corals concentrate dissolved inorganic carbon to facilitate calcification. Nat. Commun. 5, 5741 (2014).

14. Ries, J. B. A physicochemical framework for interpreting the biological calcification response to $\mathrm{CO}_{2}$-induced ocean acidification. Geochim. Cosmochim. Acta 75, 4053-4064 (2011).
15. Allison, N. \& Finch, A. A. $\delta^{11} \mathrm{~B}, \mathrm{Sr}, \mathrm{Mg}$ and B in a modern Porites coral: the relationship between calcification site $\mathrm{pH}$ and skeletal chemistry. Geochim. Cosmochim. Acta 74, 1790-1800 (2010).

16. Balestra, B., Ziveri, P., Monechi, S. \& Simon, T. Coccolithophorids from the Southeast Greenland Margin (Northern North Atlantic): production, ecology and the surface sediment record. Micropaleontology 50, 23-34 (2004).

17. Winter, A., Jordan, R. W. \& Roth, P. H. in Coccolithophores (eds Amos, W. \& William G. S.) 161-177 (Cambridge University Press, Cambridge, UK, 1994).

18. Moheimani, N. R., Webb, J. P. \& Borowitzka, M. A. Bioremediation and other potential applications of coccolithophorid algae: a review. Algal Res. 1, 120-133 (2012).

19. Westbroek, P., Young, J. R. \& Linschooten, K. Coccolith production (biomineralization) in the marine alga Emiliania huxleyi. J. Protozool. 36, 368-373 (1989).

20. Bolton, C. T. et al. Decrease in coccolithophore calcification and $\mathrm{CO}_{2}$ since the middle Miocene. Nat. Commun. 7, 10284 (2016).

21. Riebesell, U. et al. Reduced calcification of marine plankton in response to increased atmospheric $\mathrm{CO}_{2}$. Nature 407, 364-367 (2000).

22. Aloisi, G. Covariation of metabolic rates and cell size in coccolithophores. Biogeosciences 12, 4665-4692 (2015).

23. Anning, T., Nimer, N., Merrett, M. J. \& Brownlee, C. Costs and benefits of calcification in coccolithophorids. J. Mar. Syst. 9, 45-56 (1996).

24. Hemming, N. G. \& Hanson, G. N. Boron isotopic composition and concentration in modern marine carbonates. Geochim. Cosmochim. Acta 56, 537-543 (1992).

25. Rollion-Bard, C., Chaussidon, M. \& France-Lanord, C. Biological control of internal $\mathrm{pH}$ in scleractinian corals: implications on paleo-pH and paleotemperature reconstructions. C. R. Geosci. 343, 397-405 (2011).

26. Krief, S. et al. Physiological and isotopic responses of scleractinian corals to ocean acidification. Geochim. Cosmochim. Acta 74, 4988-5001 (2010).

27. Henehan, M. J. Ground-truthing the Boron-based Proxies. PhD thesis, University of Southampton (2015).

28. Suffrian, K., Schulz, K. G., Gutowska, M. A., Riebesell, U. \& Bleich, M. Cellular pH measurements in Emiliania huxleyi reveal pronounced membrane proton permeability. New Phytol. 190, 595-608 (2011).

29. Fresnel, J. \& Probert, I. The ultrastructure and life cycle of the coastal coccolithophorid Ochrosphaera neapolitana (Prymnesiophyceae). Eur. J. Phycol. 40, 105-122 (2005).

30. Inouye, I. (ed.) in Biological System of Mangroves: A report of east Indonesian mangrove expedition 35-43 (Japan, 1988)

31. Young, J. et al. A Guide to Extant Coccolithophore Taxonomy (International Nannoplankton Association, Germany, 2003).

32. Young, J. R., Davis, S. A., Bown, P. R. \& Mann, S. Coccolith ultrastructure and biomineralisation. J. Struct. Biol. 126, 195-215 (1999).

33. Marsh, M. E. Regulation of $\mathrm{CaCO}_{3}$ formation in coccolithophores. Comp. Biochem. Physiol. Part B 136, 743-754 (2003).

34. Stanley, S. M., Ries, J. B. \& Hardie, L. A. Seawater chemistry, coccolithophore population growth, and the origin of cretaceous chalk. Geology 33, 593-596 (2005).

35. Huertas, I. E., Bhatti, S. \& Colman, B. Inorganic carbon acquisition in two species of marine prymnesiophytes. Eur. J. Phycol. 38, 181-189 (2003).

36. Yu, J., Thornalley, D. J. R., Rae, J. W. B. \& McCave, N. I. Calibration and application of $\mathrm{B} / \mathrm{Ca}, \mathrm{Cd} / \mathrm{Ca}$, and $\delta^{11} \mathrm{~B}$ in Neogloboquadrina pachyderma (sinistral) to constrain $\mathrm{CO}_{2}$ uptake in the subpolar North Atlantic during the last deglaciation. Paleoceanography 28, 237-252 (2013).

37. Foster, G. L. \& Rae, J. W. B. Reconstructing ocean $\mathrm{pH}$ with boron isotopes in Foraminifera. Annu. Rev. Earth Planet Sci. 44, 207-237 (2016).

38. Tanaka, M. \& Fujiwara, T. Physiological roles and transport mechanisms of boron: perspectives from plants. Pflüg. Arch. Eur. J. Physiol. 456, 671-677 (2008).

39. Dordas, C. \& Brown, P. H. Permeability of boric acid across lipid bilayers and factors affecting it. J. Membr. Biol. 175, 95-105 (2000).

40. Stoll, H., Langer, G., Shimizu, N. \& Kanamaru, K. B/Ca in coccoliths and relationship to calcification vesicle $\mathrm{pH}$ and dissolved inorganic carbon concentrations. Geochim. Cosmochim. Acta 80, 143-157 (2012).

41. Cornwall, C. E., Comeau, S. \& McCulloch, M. T. Coralline algae elevate $\mathrm{pH}$ at the site of calcification under ocean acidification. Glob. Chang. Biol. 23, 42454256 (2017)

42. Sutton, J. N. et al. $\delta^{11} \mathrm{~B}$ as monitor of calcification site $\mathrm{pH}$ in divergent marine calcifying organisms. Biogeosciences 15, 1447-1467 (2018).

43. Klochko, K., Kaufman, A. J., Yao, W., Byrne, R. H. \& Tossell, J. A. Experimental measurement of boron isotope fractionation in seawater. Earth Planet Sci. Lett. 248, 276-285 (2006).

44. Henehan, M. J. et al. Calibration of the boron isotope proxy in the planktonic Foraminifera Globigerinoides ruber for use in palaeo- $\mathrm{CO}_{2}$ reconstruction. Earth Planet Sci. Lett. 364, 111-122 (2013).

45. Allemand, D. et al. Biomineralisation in reef-building corals: from molecular mechanisms to environmental control. C. R. Palevol 3, 453-467 (2004). 
46. Hermoso, M. et al. An explanation for the ${ }^{18} \mathrm{O}$ excess in Noelaerhabdaceae coccolith calcite. Geochim. Cosmochim. Acta 189, 132-142 (2016).

47. Ziveri, P., Thoms, S., Probert, I., Geisen, M. \& Langer, G. A universal carbonate ion effect on stable oxygen isotope ratios in unicellular planktonic calcifying organisms. Biogeosciences 9, 1025-1032 (2012).

48. Hermoso, M. Control of ambient $\mathrm{pH}$ on growth and stable isotopes in phytoplanktonic calcifying algae. Paleoceanography 30, 2015PA002844 (2015).

49. Hermoso, M., Chan, I. Z. X., McClelland, H. L. O., Heureux, A. M. C. \& Rickaby, R. E. M. Vanishing coccolith vital effects with alleviated carbon limitation. Biogeosciences 13, 301-312 (2016)

50. Moolna, A. \& Rickaby, R. E. M. Interaction of the coccolithophore Gephyrocapsa oceanica with its carbon environment: response to a recreated high- $\mathrm{CO}_{2}$ geological past. Geobiology 10, 72-81 (2012).

51. Rost, B., Zondervan, I. \& Riebesell, U. Light-dependent carbon isotope fractionation in the coccolithophorid Emiliania huxleyi. Limnol. Oceanogr. 47, 120-128 (2002).

52. McClelland, H. L. O., Bruggeman, J., Hermoso, M. \& Rickaby, R. E. M. The origin of carbon isotope vital effects in coccolith calcite. Nat. Commun. 8, 14511 (2017).

53. Hermoso, M., Candelier, Y., Browning, T. J. \& Minoletti, F. Environmental control of the isotopic composition of subfossil coccolith calcite: are laboratory culture data transferable to the natural environment? GeoResJ 7, 35-42 (2015).

54. Kottmeier, D., Rokitta, S., Tortell, P. \& Rost, B. Strong shift from $\mathrm{HCO}_{3}-$ to $\mathrm{CO}_{2}$ uptake in Emiliania huxleyi with acidification: new approach unravels acclimation versus short-term pH effects. Photosynth. Res. 121, 265-275 (2014).

55. Bach, L. T. et al. Dissecting the impact of $\mathrm{CO}_{2}$ and $\mathrm{pH}$ on the mechanisms of photosynthesis and calcification in the coccolithophore Emiliania huxleyi. New Phytol. 199, 121-134 (2013).

56. Zeebe, R. E. \& Wolf-Gladrow, D. A. $\mathrm{CO}_{2}$ in Seawater: Equilibrium, Kinetics, Isotopes. Vol. 65 (Elsevier, Amsterdam, 2001).

57. Zeebe, R. E. An expression for the overall oxygen isotope fractionation between the sum of dissolved inorganic carbon and water oxygen isotopes. Geochem. Geophys. Geosyst. 8, G3 (2007).

58. Spero, H. J., Bijma, J., Lea, D. W. \& Bemis, B. E. Effect of seawater carbonate concentration on foraminiferal carbon and oxygen isotopes. Nature $\mathbf{3 9 0}$, 497-500 (1997).

59. Tripati, A. K. et al. Beyond temperature: clumped isotope signatures in dissolved inorganic carbon species and the influence of solution chemistry on carbonate mineral composition. Geochim. Cosmochim. Acta 166, 344-371 (2015).

60. Ries, J. B. Review: geological and experimental evidence for secular variation in seawater $\mathrm{Mg} / \mathrm{Ca}$ (calcite-aragonite seas) and its effects on marine biological calcification. Biogeosciences 7, 2795-2849 (2010).

61. Stevenson, E. I. et al. Controls on stable strontium isotope fractionation in coccolithophores with implications for the marine Sr cycle. Geochim. Cosmochim. Acta 128, 225-235 (2014).

62. Langer, G. et al. Species-specific responses of calcifying algae to changing seawater carbonate chemistry responses of calcifying algae. Geochem. Geophys. Geosyst. 7, Q09006 (2006).

63. Atkinson, M. Elemental composition of commercial seasalts. J. Aquariculture Aquat. Sci. 8, 39 (1999).

64. Guillard, R. R. L. \& Ryther, J. H. Studies of marine planktonic diatoms: I. Cyclotella nana Hustedt, and Detonula confervacea (Cleve) Gran. Can. J. Microbiol. 8, 229-239 (1962)

65. Krug, S. A., Schulz, K. G. \& Riebesell, U. Effects of changes in carbonate chemistry speciation on Coccolithus braarudii: a discussion of coccolithophorid sensitivities. Biogeosciences 8, 771-777 (2011).

66. Zondervan, I., Rost, B. \& Riebesell, U. Effect of $\mathrm{CO}_{2}$ concentration on the PIC/ POC ratio in the coccolithophore Emiliania huxleyi grown under lightlimiting conditions and different daylengths. J. Exp. Mar. Bio. Ecol. 272, 55-70 (2002).

67. Guillard, R. R. L. in Culture of Marine Invertebrate Animals: Proc. - 1st Conference on Culture of Marine Invertebrate Animals Greenport (eds Walter, L. S. \& Matoira, H. C.) 29-60 (Springer US, Boston, MA, 1975).

68. Program developed for $\mathrm{CO}_{2}$ system calculations. ORNL/CDIAC-105 (Carbon Dioxide Information Analysis Center, Oak Ridge National Laboratory, U.S. Department of Energy, Oak Ridge, 1998).

69. Roy, R. N. et al. The dissociation constants of carbonic acid in seawater at salinities 5 to 45 and temperatures 0 to $45^{\circ} \mathrm{C}$. Mar. Chem. 44, 249-267 (1993).

70. Mucci, A. The solubility of calcite and aragonite in seawater at various salinities, temperatures, and one atmosphere total pressure. Am. J. Sci. $\mathbf{2 8 3}$, 780-799 (1983).

71. Barker, S., Greaves, M. \& Elderfield, H. A study of cleaning procedures used for foraminiferal $\mathrm{Mg} / \mathrm{Ca}$ paleothermometry. Geochem. Geophys. Geosyst. 4, 8407 (2003).

72. Liu, Y.-W., Aciego, S. M., Wanamaker, A. D. \& Sell, B. K. A high-throughput system for boron microsublimation and isotope analysis by total evaporation thermal ionization mass spectrometry. Rapid Commun. Mass Spectrom. 27, 1705-1714 (2013)

73. Brand, W. A., Coplen, T. B., Vogl, J., Rosner, M. \& Prohaska, T. Assessment of international reference materials for isotope-ratio analysis (IUPAC Technical Report). Pure Appl. Chem. 86, 425 (2014).

74. Coplen, T. B. et al. Compilation of minimum and maximum isotope ratios of selected elements in naturally occurring terrestrial materials and reagents. Report No. 01-4222 (Geological Survey Water-Resources Investigations, 2002).

75. Gerecht, A. C., Šupraha, L., Edvardsen, B., Probert, I. \& Henderiks, J. High temperature decreases the PIC/POC ratio and increases phosphorus requirements in Coccolithus pelagicus (Haptophyta). Biogeosciences 11, 3531-3545 (2014).

76. Hendy, I. L., Napier, T. J. \& Schimmelmann, A. From extreme rainfall to drought: 250 years of annually resolved sediment deposition in Santa Barbara Basin, California. Quat. Int. 387, 3-12 (2015).

77. Aciego, S. M. \& Sell, B. K. Devices for separating boron from carbonate. US patent no. US9556036 B2 (2017).

78. Foster, G. L., Ni, Y., Haley, B. \& Elliott, T. Accurate and precise isotopic measurement of sub-nanogram sized samples of foraminiferal hosted boron by total evaporation NTIMS. Chem. Geol. 230, 161-174 (2006).

79. Liu, Y.-W., Aciego, S. M. \& Wanamaker, A. D. Jr. Environmental controls on the boron and strontium isotopic composition of aragonite shell material of cultured Arctica islandica. Biogeosciences 12, 3351-3368 (2015).

80. DOE. Handbook of Methods for the Analysis of the Various Parameters of the Carbon Dioxide System in Sea Water. Version 2. ORNL/CDIAC-74 (Carbon Dioxide Information and Analysis Center, Oak Ridge, 1994).

\section{Acknowledgements}

We thank J. Sutton and A. Tripati for making helpful edits to the manuscript and I. Westfield for analyzing the carbonate chemistry of the experimental seawater treatments. We also thank I. Probert for assisting with SEM imaging at Roscoff Marine Station. This project was funded by a Packard Fellowship to S.M.A. and National Science Foundation grants OCE-1437166 to R.A.E., and OCE1437371 and OCE-1357665 to J.B.R. R.A.E. is also funded by LabEx International Research Chair that is co-funded by the "Laboratoire d'Excellence" LabexMER (ANR-10-LABX-19) and a grant from the French government under the programme "Investissements d'Avenir."

\section{Author contributions}

R.A.E. and J.B.R. conceived the original study. R.A.E., S.M.A., Y.-W.L., R.E.G. and J.B.R designed the research. R.E.G. and J.B.R. performed the culture experiment. Y.-W.L. performed the isotope, PIC/POC and SEM analyses, analyzed the data and drafted the original manuscript with inputs from S.M.A., R.A.E. and J.B.R. All authors contributed to revising the manuscript.

\section{Additional information}

Supplementary Information accompanies this paper at https://doi.org/10.1038/s41467018-04463-7.

Competing interests: The authors declare no competing interests.

Reprints and permission information is available online at http://npg.nature.com/ reprintsandpermissions/

Publisher's note: Springer Nature remains neutral with regard to jurisdictional claims in published maps and institutional affiliations.

Open Access This article is licensed under a Creative Commons Attribution 4.0 International License, which permits use, sharing, adaptation, distribution and reproduction in any medium or format, as long as you give appropriate credit to the original author(s) and the source, provide a link to the Creative Commons license, and indicate if changes were made. The images or other third party material in this article are included in the article's Creative Commons license, unless indicated otherwise in a credit line to the material. If material is not included in the article's Creative Commons license and your intended use is not permitted by statutory regulation or exceeds the permitted use, you will need to obtain permission directly from the copyright holder. To view a copy of this license, visit http://creativecommons.org/ licenses/by/4.0/.

(C) The Author(s) 2018 